\title{
A new type of cities for liveable futures Isobenefit Urbanism morphogenesis
}

\author{
Luca D'Acci \\ Politecnico di Torino, Interuniversity Department of Regional and Urban Studies and Planning \\ Erasmus Universiteit Rotterdam, Erasmus School of Social and Behavioural Sciences, and Institute for Housing and Urban Development Studies \\ D’Acci L. (2019). A new type of cities for liveable futures. Isobenefit urbanism \\ morphogenesis. Journal of Environmental Management (in press)
}

\begin{abstract}
We need a conceptually different idea of cities which paradigmatically shifts their forms and structures toward more liveable future environments, both for us and our planet. The Isobenefit Urbanism is conceived within a medium-long term perspective mixing a macro top-down planning with a micro bottom-up spontaneous evolution in an attempt to moderate the human forces which typically induce agglomeration benefits and costs, maintaining the former while limiting the latter. It indicates a simple efficient urban genetic code to generate cities that are walkable, carless, low carbon, adaptive, connected, compact, multifunctional settlements throughout nature, with unplanned forms and unlimitedly extendible, in which one can feel both urbanity and nature. They are flexible cities and dynamically changeable. By holding constant the number of inhabitants of a usual city or megacity, its counterpart Isobenefit city would enjoy the same economies of scale benefits but without their costs. The Isobenefit Urbanism model might offer a potential solution to current issues of wild cementification, urban heat island effects, destruction of natural land and biodiversity, carbon emissions, congestions and related air pollution, as well as provide an urban model to host the enormous new urban inhabitants our world must accommodate in the next few decades. Its ultimate ambition is to enjoy the economies of agglomeration without incurring to the diseconomies of agglomeration, manifested by sublinear and superlinear outputs, typically infrastructural the former and socioeconomic the latter.
\end{abstract}

\section{Highlights}

- This new urban type enhances agglomerations' benefits while avoiding their costs

- This single urban genotype induces potential infinite urban phenotypes

- It is an urban model proposing a new relation between urban and natural lands

- $\quad$ Free markets versus planning tactics are discussed for real estate developments 


\section{Introduction: managing the future city}

The futurist architect Richard Buckminster Fuller (1895-1983) once said "you never change things by fighting the existing reality. To change something, build a new model that makes the existing model obsolete". Thought in line with the futurist Alvin Toffler ("we must learn how to discard old ideas, how and when to replace them" Toffler 1970 p. 374), with the sociologist-historian Frank Wilson Blackmar ("It is only by departure from established tradition that progress is made possible" Blackmar 1923, p. 11,12), the young historian Rutger Bregman ("the inability to imagine a world in which things are different is evidence only of a poor imagination, not of the impossibility of change" Bregman 2016, p. 199), and the Lefebvre's utopian message (" [...] without utopia [...] a person is content to record what he sees before his eyes" Lefebvre, 2009 [1970], p. 178).

The unpredictability of the future city does not impede us to have a knowledgeable discussion about it (Batty 2018, xii) or to invent ${ }^{2}$ it (Gabor 1963, p.161).

Most planetary problems such as climate change, biodiversity loss, ecological degradation, pollution, as well as humans psychological and physical well-being are linked with degenerative urban design.

The latter is often generated and fed from the market rather than planning, even though frequently it is the other way around too. Although the market's relatively spontaneous, self-regulated process resulting in the natural emergence of cities' size, structure and form has positive aspects, such as generating a type or order without designing it ${ }^{3}$, it needs to be controlled-guided when the type of phenomena which it generates, clearly and objectively do not improve our quality of life": "the objective of planning regulations is to modify the outcome of unconstrained markets to increase the welfare of citizens" (Bertaud 2018, p.1).

We need to think of new typologies of cities, and processes to induce them, which are not prominently driven by market forces alone and which account for an overall better environment and life.

Assuming the case that in our future we will still have cities ${ }^{5}$ we need to imagine ways to make them livable, especially if the current rate of urbanization will not reverse (Zhang 2008, Merrifield

1 "In order to extend the possible, it is necessary to proclaim and desire the impossible. Action and strategy consist in making possible tomorrow what is impossible today" Henri Lefebvre (1976 [1973], p. 36), in Pinder 2013.

2 Also a scientific visionary of our age, James Lovelock, prefers to use the terms "invention" when describing that "in reality what moves us and the world is another form of intelligence: intuition and invention" (Lovelock 2014, p. 84).

3 "The order created by markets manifests itself in the shape of cities. Market transmits through prices the information generating the spatial order" (Bertaud 2018, p.1)

${ }^{4}$ The great efficiency and autonomy of the liberal forces of the market must be recognized, however "it only values what is priced and only delivers to those who can pay. Like fire, it is extremely efficient at what it does, but dangerous if it gets out of control. When the market is unconstrained, it degrades the living world $[\ldots]$ it also fails to deliver public goods $[\ldots]$ market's power must be wisely embedded within public regulations" (Raworth 2018, p. 81, 82).

"We can ask how deeply we want to $[\ldots]$ make a thoughtful decision about how $[\ldots]$ we want our surroundings to be. [...] The biggest tragedy would be for us to allow these decisions to be made on our behalf, without our input, by market-driven forces. It is a terrible misunderstanding $[\ldots]$ to assert that markets simply reflect what people want. [...] Decisions on those channels are not made with the public's needs or interests in mind. They are opportunistic decision based on financial promise." (Preston 2018, p. 114).

5 Probably cities will exist until agglomeration economies (McCann and van Oort 2009), in their broadest sense, exceed or at least level (subjectively and/or objectively, in reality, in the perceptions, or in the expectations) agglomeration diseconomies. The traditional way to achieve agglomeration economies is by proximity, being close, meaning density. Authors such as Naisbitt (1995), Negroponte (1995), Knoke (1996), Toffler (1980) and many others advance the idea that we will not live in cities thanks to the new 
2013), indicating the dramatic need to expand/add cities and that a better city will offer a better life (Cloutier, Larson \& Jambeck 2013, van Kamp, Leidelmeijer, Marsman \& de Hollander 2003, Jackson 2003, Matsuoka \& Kaplan 2008) to millions of citizens.

The current world population (May 2019) is around 7.7 billion $^{6}$, of whom around 4 billion in cities. According to the most recent (16 June 2018) report of the Population Division of the Department of Economic and Social Affairs of the United Nations "the overall growth of the world's population could add another 2.5 billion people to urban areas by 2050 , with close to $90 \%$ of this increase taking place in Asia and Africa [...] The urban population of the world has grown rapidly from 751 million in 1950 to 4.2 billion in 2018"7 (World Urbanization Prospects 2018, UN).

Put in other terms, the entire urban world population we had in the 1990s (around 2 billion) "accumulated" in more than 200 thousand years of human history, are going to be added all in one go in the next 30 years only and almost entirely in two continents.

This fact alone is sufficient to underline the urgency for not only an economic paradigm shift (Raworth 2018) for the challenges of the $21^{\text {st }}$ century but a truly and drastic urban model shift.

According to recent estimates the most likely population growth scenario might be a logistic Sshaped curve in which a global population of 10-11 billion would eventually stabilize in the $22^{\text {nd }}$ century, and probably entirely urban. Even under this stabilized world population size, the pressure is still to dramatically change our city shapes, structure and link with natural lands for the current citizens, and to host these additional around 3 billion urban dwellers.

The physical growth, urban forms and structures of our cities cannot be entirely left to the laissezfair because of the contemporaneity of two events: the rapidity and the magnitude of this urban unprecedented growth which does not allow, as the pre-industrial time efficiently and pleasantly often did, a spontaneous bottom-up emergence of somehow liveable and sustainable evolution of our cities and of the global environment. The rapidity of this growth (around 2 billion additional urban dwellers in the next 30 years only just in Africa and Asia) and its magnitude make it hard for the self-organization process to successfully adapt in their feedbacks of auto-corrections and to constantly adjust (within a reasonably short time) the urban system in a sustainable liveable way. A clear strategic and responsible management (Conaway and Laasch 2014, Brandon et al. 2017), and guide for the conceptions, edifications and transformations of our artificial habitats (cities and megacities) and the preservation of the natural environment is becoming a must.

Within the intricate interplay of positive and negative feedbacks inherent in the complex, spontaneous emergence from retroactive games among countless urban actors, the outcome in terms of overall quality/liveability of an urban form, nowadays more than ever, depends on the set of rules and regulations and their implementation.

technology in telecommunications, while others, such as Gaspar and Glaeser, believe that "telecommunications may be a complement to, or at least not a strong substitute for, cities and face-to-face interactions" (Gaspar \& Glaeser 1998, p. 136). The need for face-to-face interaction is an atavistic reminiscence in our DNA as we are part of the social animals group. Some may have a more solitary nature, some a more sociable one, but we are still herd animals (in our hunter-gatherer existence covering more than $99 \%$ of our time the basic unit - the family - was of 5-8 persons, which can aggregate in a camp of 46 families, 25-50 persons, and regional networks of 10-20 camps, 250-500 persons. Johnson and Earle, 2000, p. 32, 33, 41, 50, 51, 54-57, 63, 88; Bye et al.,1987; Isaac, 1978; Wenke, 1980; Kelly, 1995; Blumenschine, 1995) with the need for human contact, social rewards, emotional exchanges, which, even if they are possible with the new information technology too, they are (still) not able to substitute a genuine face-to-face contact.

${ }^{6}$ http://www.worldometers.info/world-population/

${ }^{7}$ https://www.un.org/development/desa/en/news/population/2018-revision-of-world-urbanizationprospects.html 


\section{The aim of Isobenefit Urbanism}

The aim of the urban planning approach that will follow is to present a new model, a new idea of cities, a shift in the urban model mindset.

The new city typology proposed mixes soft top-down planning with spontaneous emergence from local contexts; it is a city emerging as a sum of walkable, connected, compact multifunctional settlements throughout/surrounded by nature, without planned fixed forms and unlimitedly extendible, in which one can feel urbanity and nature.

In a certain way, with the genetic urban code allowing flexible and infinite urban phenotypes we will present in these pages, we take the challenge launched from Pinder (2010) to "reconceptualise utopian urbanism in more open and process-oriented ways" (p. 238), engaging it "with the current complexities of urban spaces and processes" (p.237).

What follows are examples of cities generated by a plan code (which we can call the Isobenefit Urbanism genotype) aiming to stimulate debates and thoughts about possible spatial solutions for hosting these additional billions of urban dwellers in the coming four decades, as well as to transform our existent cities and megacities into walkable zero-carbon output and in a way to keep the numerous advantages of proximity to natural land.

Cities produce $80 \%$ of the world's greenhouse gases (Swyngedouw 2009, p. 602), and their relative climate change negative effects; cities which are low carbon (Lehmann 2014, Carvalho, Bonifacio \& Dechamps 2011, Bulkeley, Castan-Broto, Hodson \& Marvin 2011, Seyfang 2010, Skea \& Nishioka 2008, Moloney, Horne \& Fien 2010, Gomi, Shimada, Matsuoka \& Naito 2007, Chatterton 2013), adaptive and resilient (Bowler, Buyung-Ali, Knight, Pullin 2010) are the requirement.

In China alone, three hundred million people are expected to move to cities in the next 15 years, and in the $21^{\text {st }}$ century cities will account for $90 \%$ of the population growth, $80 \%$ of the CO2 emissions and $75 \%$ of the world's energy use (Larson 2012); these numbers assess the urgent need to establish new ways to think about and design cities.

Urban areas use $60-80 \%$ of the global energy produced and generate more than $70 \%$ of global GHG emissions (Fragkias 2013), inside which transport is a major source, in fact, in developed countries, the CO2 emissions from the transport sector are around 30\% of the total (Mohajeri, Gudmundsson and French 2015, p. 117), and, in some cases, around 90\% of which come from vehicles (www.dft.gov.uk).

Different sizes $^{8}$, forms and structures ${ }^{9}$ of the urban areas influence transport systems, moving lengths, congestion, emissions and energy and land use; among them, the dispersed urban model, from which several environmental issues often arise ${ }^{10}$, is mostly typical of North America, as Kasanko et al (2006) pointed out, but it is becoming a European phenomenon too: "since the mid1950's, European cities have expanded on average by $78 \%$ whereas the population has grown by only 33\%; also, more than $90 \%$ of the new residential areas are low-density ones (Kasanko et al., 2006)" (Martins 2012, p.60).

\footnotetext{
${ }^{8}$ Batty $(2014$, 2018), Bettencourt (2013), Fragkis et al. (2013), Louf \& Barthelemy (2014a,b), Oliveira et al. (2014), Mohajeri et al. (2015).

9 Aguiléra \& Voisin (2014), Banister (2012, 2007a,b), Borrego et al. (2006), Brownstone \& Golob (2009), Chen et al. (2011), Dodman (2009), Echenique et al. (2015), Giuliano \& Small (1993), Glaeser \& Kahn (2010), Gordon \& Wong (1985), Grazi et al. (2008), Heinonen et al. (2013), Hickman \& Banister (2014), Holden \& Norland (2005), Keirstead \& Shah (2011), Kennedy et al. (2011), Lee \& Lee (2014), Li \& GarOn Yeh (2000), Liu \& Shen (2011), Liu et al. (2012), Lowry \& Lowry (2014), Ma \& Banister (2007), Makido et al. (2012), Martins (2012), McCarty \& Kaza (2015), McIntosh et al. (2014), Mindali et al. (2004), Mitchell et al. (2011), Mohajeri et al. (2015), Schubert et al. (2013), Schwanen (2002), Schwanen et al. (2001, 2002, 2004), Wang et al. (2015), Wang et al. (2014).

${ }^{10}$ See previous footnote, plus the 2018 Report of The Global Commission of the Economy and Climate, The New Climate Economy https://newclimateeconomy.report/2018/cities.
} 
Whether generated by a planning wish or by a bottom up evolution the dispersed city is nowadays one the biggest problems for the environment and our quality of lives, and one of the urban form typology that Isobenefit Urbanism intentions to substitute by proposing alternative ideas.

Besides objective, quantifiable environmental issues ${ }^{11}$ and economic costs ${ }^{12}$ linked with spread urban areas and car dependent cities, there are psychological considerations to evaluate too regarding urban size $\mathrm{e}^{13}$ and natural contact ${ }^{14}$. By building our cities in the current way which typically involves a long commute to be able to reach a proper natural contact, we build our lives' constrictions too, by forcing us to underlive (conscious of it or not) the full psychological and physical wellbeing we could actually experience.

Inside this climate change and environmental, socio-psycho-economic urgent necessities, Isobenefit Urbanism aims to play a fundamental role in the urban morphogenesis process by inducing new forms and urban structures mitigating and adapting to climate change issues as well as creating more efficient urban-regional economies, quality of human urban life and natural preservation.

\section{Speculations about visionary urban future scenarios}

There is a historical querelle (Williams et al., 2000) about the greenest urban form being the compact or the dispersed, particularly in terms of energy/CO2/pollution/congestion per capita. However, if we reason at a global level, the habitable surface on the Earth is around 64 million $\mathrm{Km}^{2}$, the current world population is around 7.7 billion people (Fig. 1), therefore $0.008 \mathrm{Km}^{2}$ per capita, namely around a square of $90 \mathrm{mt}$ side for each person $(60 \mathrm{mt}$ if with 11 billion people in 60 years), and this without calculating the surface needed for agriculture, farms, factories, streets, energy sources, schools, hospitals, shops, amenities...

This makes clear how the problem posed in this term becomes merely geometrical and doesn't leave many rational windows open to many concrete possibilities which, regardless the probable persistence of Zipfs law distribution of city sizes (perhaps flattering the regression line's slope of the log-log rank-size plot as we are already assisting since the middle of the $20^{\text {th }}$ century ${ }^{15}$ ), we can symbolically and visionarily speculate in the following image (Fig. 2).

The first scenario is a single global immense city densely compacted in one location alone hosting the entire world population ${ }^{16}$ : we can call her Urbs Singularis. This could probably be a good solution

\footnotetext{
${ }^{11}$ See the previous three footnotes.

12 Pollution related health costs: $5 \%$ of GDP in cities in developing countries, over $90 \%$ of which can be attributed to vehicle emissions; urban road accidents in developing country cities alone cost $2 \%$ of GDP; social costs of road transport in OECD countries, China and India: \$3,5 trillion/year; in 1995 transport costs in transit-oriented Singapore were $\$ 10$ billion less than in car-oriented Houston (both with similar population size and wealth); urban sprawl costs the US $\$ 400$ billion per year; sprawling Houston spends $14 \%$ of its GDP on transport compared with $4 \%$ in relatively compact Copenhagen, and $7 \%$ typically in Western European cities; compact, connected urban development could reduce global infrastructure requirements by more than $\$ 3$ trillion in 15 years (2015-2030):

for more details see the 2014 Report of The Global Commission of the Economy and Climate, The New Climate Economy, Chapter Two, Cities Engines of National and Global Growth https://newclimateeconomy.report/2014/cities.

${ }^{13}$ See, among many, Easterlin at al. (2011), Okulicz-Kozaryn (2015), Sørensen (2014).

${ }^{14}$ For a discussion about our species' (bomo sapiens) needs for natural contact, a classic is Wilson 1986.

${ }^{15}$ See a concise and technically accessible description in Batty 2018.

${ }^{16}$ If the entire current world population (around 7.67 billion) would live in a single city with a same density of the densest areas of Honk Kong ("measured at block level some areas may have population densities of more than 400,000 people per square kilometre" (Yeh, 2011, https://urbanage.lsecities.net/essays/highdensity-living-in-hong-kong, it would be enough a square of just $138 \mathrm{~km}$ side, above which we should add the surface necessary for industries, services, energy production, agriculture and so on.
} 
for 'nature' as it would undisturbedly have the major part of the planet without many human interferences. However, it might not be ideal for humans, especially those living in the core of such Urbs Singularis, because of (even assuming that by that time we solved congestion related costs, transport efficiency, urban heat island effects, flooding, pollution, and all the issues currently connected to city size) losing the daily contact with nature and the psychological cost of being immersed in a compact megabox of billions of people. Nevertheless, we imagine that in that future we will have hyper fast public transport ways (e.g. sky train, underground and sky hyperloop) to pleasantly, cheaply and quickly reach the external border of the Urbs Singularis where only uncontaminated nature exists.

\section{WORLD: Total Population}

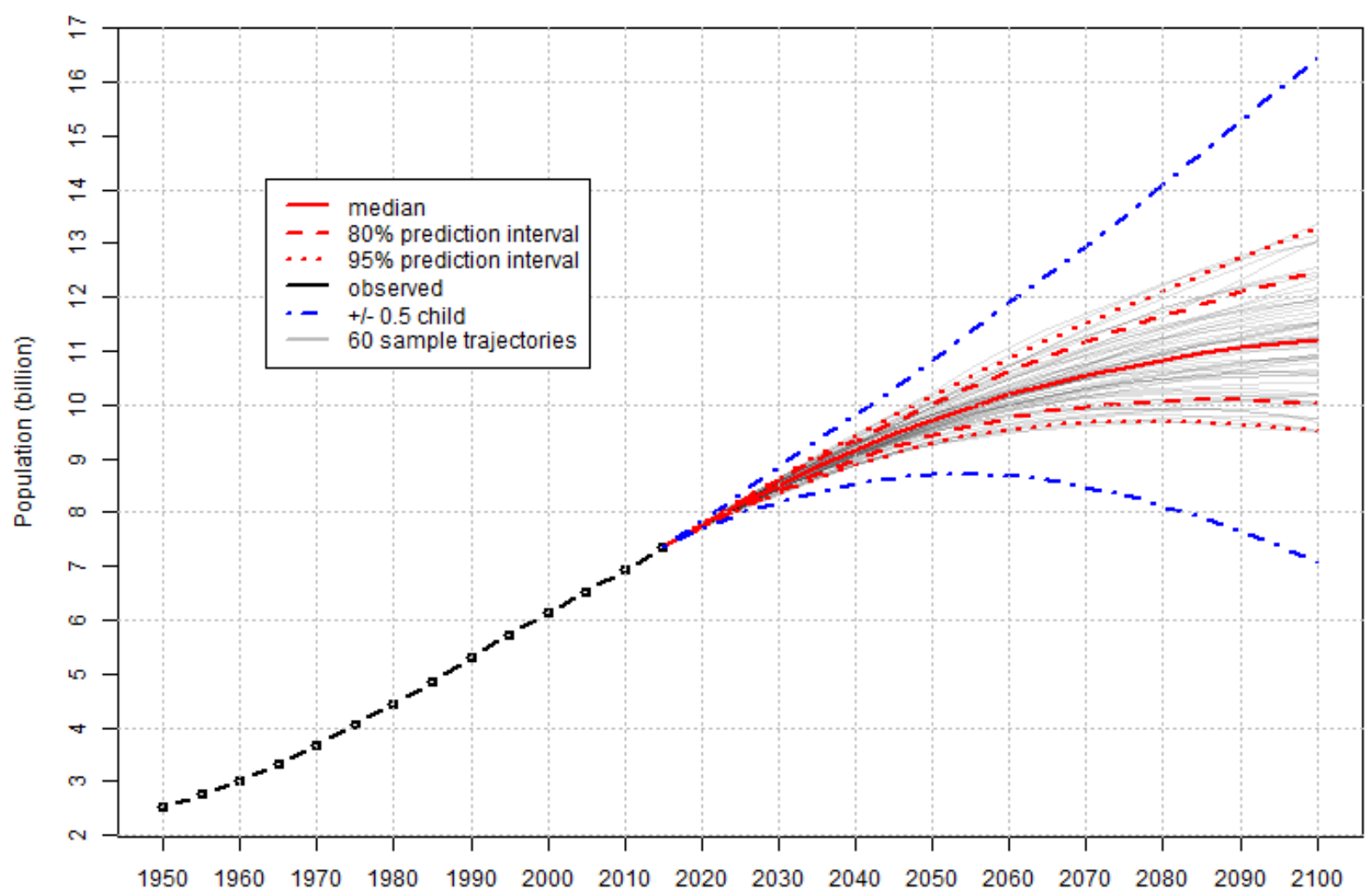

Fig 1 World population projections $2100^{17}$. Source: http://esa.un.org/unpd/wpp/Graphs

\footnotetext{
17 "These charts show estimates and probabilistic projections of the total population for countries or areas, geographical aggregates and World Bank income groups as defined in Definition of Regions. The population projections are based on the probabilistic projections of total fertility and life expectancy at birth, based on estimates of the 2015 Revision of the World Population Prospects. These probabilistic projections of total fertility and life expectancy at birth were carried out with a Bayesian Hierarchical Model. The figures display the probabilistic median, and the 80 and 95 per cent prediction intervals of the probabilistic population projections, as well as the (deterministic) high and low variant $(+/-0.5$ child) of the 2015 Revision of the World Population Prospects". Source: http://esa.un.org/unpd/wpp/Graphs.
} 


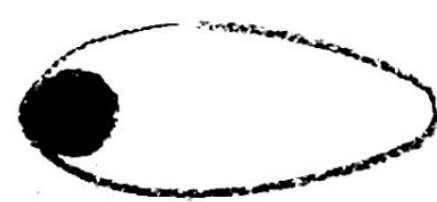

I URBS SINGULARIS

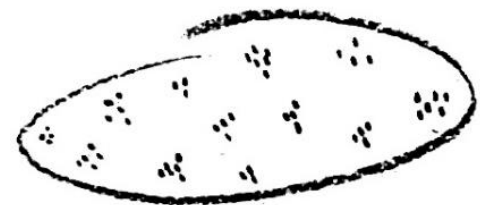

IV POLYCENTRIC URBAN REGION

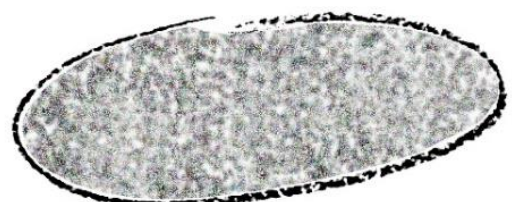

II SUBURBS SINGULARIS

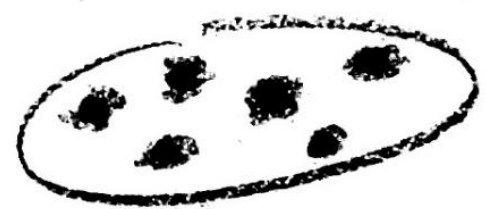

V HYPER MEGACITIES

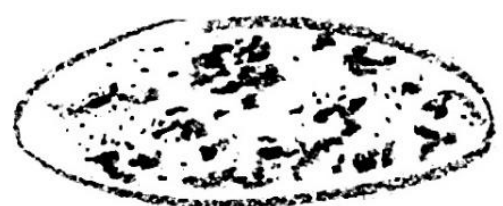

III DISPERSA MEGAURBS MIXTUS

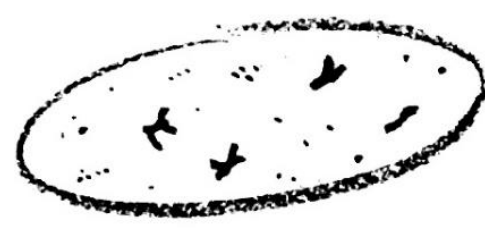

VI COMPACTUS URBS MIXTUS

Fig 2 Visionary global urban future scenarios

The second scenario is a single global extremely low density city entirely dispersed, uniformly covering the entire world's habitable surface: we can call her Suburbs Singularis. This scenario would not be beneficial for nature because she would not reach the minimum continuous size for a proper ecosystem anywhere. For our humans angle it might be beneficial because each of us, if wanting, could live in her own single family house with garden but at the cost to renounce both the urbanity and the natural experience. It would also not be easily possible to efficiently provide infrastructures and to move around by public transport systems, therefore compromising proximity externalities advantages.

The third scenario is an extended version of the long term consequence of current trends which we can call Dispersa MegaUrbs Mixtus: a mix of natural lands, villages, towns, cities, megacities, in which the latter two are far more predominant and most of them (villages, towns, cities, megacities) assembled in conurbation, overlapping/adjacent and spread patterns resulting in a serious limitation of natural space and ecosystems as well as of the urbanity atmosphere.

The fourth scenario is a worldwide series of Polycentric Urban Regions (Meijers 2007, Hall \& Pain 2006, Camagni and Salone 1993) in which several compact medium size cities reciprocally distant $20-50 \mathrm{~km}$ are overall very well connected in a morphological and functional net, allowing them to act as a single megacity of equivalent population.

The fifth scenario is a few Hyper-megacities around continents hosting almost entirely the global population.

The sixth scenario is the Compactus Urbs Mixtus: a balanced spontaneous division of inhabitants among natural, rural, village, town, city and megacity environments, where villages, towns, cities and megacities are well compacted and with clear borders. It offers a rich variety of life and environment experiences ranging from rural to megacity atmospheres. The megacities, cities and towns of this last scenario would follow the Isobenefit Urbanism genotype which is exposed in the following paragraphs, which can be adopted at any settlement scale: town, city, and megacity.

Current trends seem to point toward scenario III, which, together with the speculative (most likely not realistically happening) scenario II, is probably the worst in saving biologically productive areas, increasing car dependence, energy, CO2 and pollution emissions, and losing the urbanity feeling.

This present urban system is, to use the terms of the visionary landscape urbanist Lyle, "a degenerative system, devouring the sources of its own sustenance" (Lyle 1994, p. 5).

We have inherited degenerative capitalistic mindsets, economics and cities which we must now transform into regenerative by governance, planning and design. It is "an extraordinary challenge $[\ldots]$ inspiring next generation of smart engineers, architects, urban planners and designers [...] It 
is clearly time [...] to step up to the design table and take a sit alongside those innovative architects [...] who are spearheading the regenerative design revolution" (Raworth 2018, p. 242).

Nevertheless, before jumping into systems (as cities, environments and societies) with mega planning, management and governance, we should observe their natural evolutions, their histories, and treasure their own self-maintenance and self-generating capacities (from medieval towns to mega conurbations), learning both their positive and negative effects.

Planning, management, governance should play their role to firmly avoid negative effects of spontaneous system evolution while maintaining, or even enhancing, the positive aspects of their self-organization potential.

The urban evolution model proposed by the Isobenefit Urbanism genotype doesn't involve the size of cities but only their forms, structures and relations with natural land. The size of cities is determined by a complex interrelated mix of antagonist forces and networks (physical or not) naturally emerging and dynamically balancing from economic geography and socio-psychological behavioural sciences (for more details see, among a tremendous literature on the subject, Fujita, Krugman \& Venables 2001, Brakman, Garretsen \& van Marrewijk 2011, Glaeser 2008). However, the walkability, carlessness and greenness, linked with the close temporal proximity among city areas, characterizing Isobenefit Urbanism forms, might indirectly, spontaneously influence the urban size too because it could tend to push further away the economies-diseconomies (objective and/or perceived) of agglomeration balance point.

\section{Isobenefit Urbanism}

Iso-benefit means "equal benefit". The benefit considered is the one deriving from the advantages which city dwellers receive from the urban morphology, urban structure, transport systems, nature, activities and amenity locations.

The Isobenefit Urbanism approach aims to dynamically and flexibly design cities where each dweller enjoys a walkable access to the main daily services, job locations, urban centers and nature.

The Isobenefit morphogenesis outputs could be beneficial for aspects related to the environment (natural land and biodiversity preservation), climate change (urban heat island, flooding, carbon emission, ...), urban quality of life (congestion, daily natural contact, pollution, commuting time, car-free aesthetical/noise urban environments, ...).

Its relevance resides in mixing top-down and bottom-up growths, utopia and complexity, master plans and spontaneity, control and emergence, and in proposing a new idea about the relation between nature and city.

\subsection{Urban Centralities and Fuzzy Urban Quality}

Proposing a separation between Pleasantness given from city Centralities (Centralities Pleasantness: CP) and Pleasantness given from the Background 'daily urban quality' (Background Pleasantness: BP) we can think of a city centrality as an area with a high level of concentration of public cultural assets (libraries, museums, art galleries, etc.), and/or higher order commercial and retail functions, and/or notable and memorable historic buildings and spaces, etc. (Bianchini 1990, Evans 1997).

In addition to the 'concentration of several attractions', we also refer as city centralities, single amenities which are attractive enough to be important at a city level (i.e. Ibirapuera Park in São Paulo, Valentino Park in Turin, Central Park in New York, Regent's Park in London, etc.).

A centrality is an area which attracts all the neighbourhood and eventually citizens from the entire city (Fig. 3).

Excluding citizens living directly in, or close to, a city centrality, CP is connected to the will of going to a city centrality, while BP derives from the pleasantness given from the city's beauties 
present in our daily lives: where we are living and working, or passing through, such as a local little garden or square, the average quality of the streets, and so forth. CP is at "city level"; BP is at "local level", "Fuzzy" Urban Quality (Fig. 3).

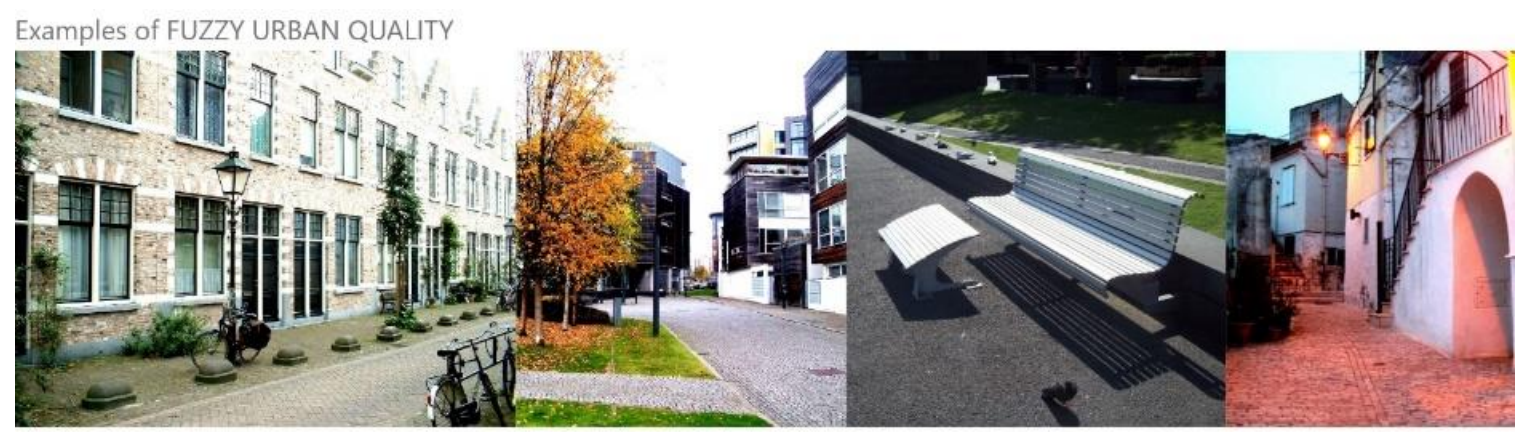

Examples of CENTRALITIES

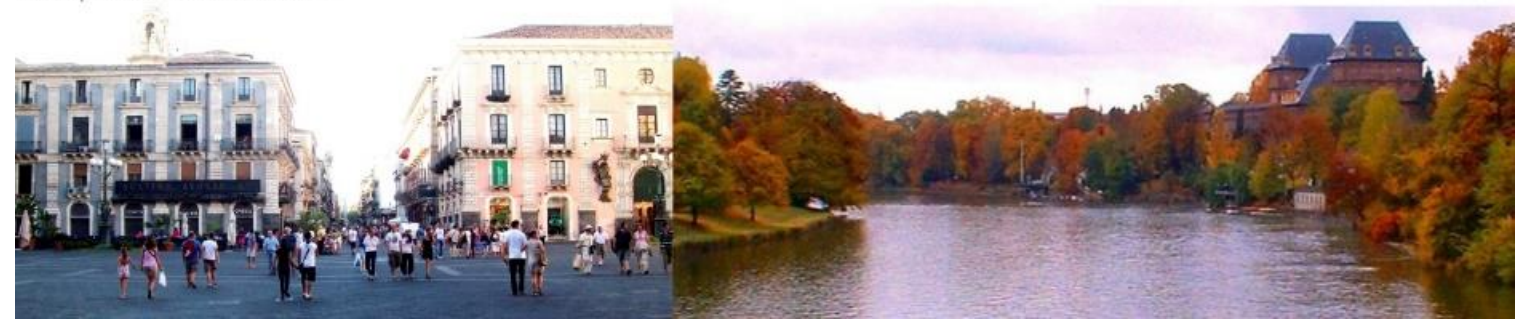

Fig 3. Top from left to right, examples of fuzzy urban quality: Rotterdam (a graceful and clean street), Melbourne (elegant bench), Glasgow (nice design of buildings, pavements and green corners), Candela (intimate lighting and flooring). Top from left to right, examples of centralities: Catania (a pedestrian square in the city centre), Torino (a linear park along the river). Source: author's photos

\subsection{The Isobenefit Urbanism genotype}

If we like to write the Isobenefit Urbanism Principles in a concise way, we could use this rough expression, which does not add information and the reader could easily jump:

$$
\begin{aligned}
& \text { 1. } \forall k \in \mathrm{M} \quad B_{k}=\sum_{i} B_{i, k}=c \geq c^{*} \wedge F=c \\
& \text { 2a. } T_{d, k} \leq T^{*} \\
& \text { 2b. } C \in \mathrm{M} \mid \forall k \quad d_{C-k} \leq T^{*} \wedge C_{1} \neq C_{2} \neq \ldots \neq C_{n} \\
& \text { 2c. } \exists N \in \vee \notin \mathrm{M} \mid \forall k \quad d_{N-k} \leq T^{*} \\
& \text { 3. } \sum \text { adjacent } k \wedge \sum \text { adjacent } N \geq 1 \mathrm{~km}^{2} \text { and connected }
\end{aligned}
$$

The above is read as the following:

1. The city is a matrix $(M)$ of point $(k)$, where $B_{i, k}$ is the benefit in $k$ given from point $i$ : when $i$ is a neutral point, there will be no benefit; when there is an amenity there will be a benefit; when there is a disamenity there will be a negative "benefit". The overall benefit a point receives from the entire urban points should tend to be "constant" $(c)$ everywhere for each k. Idem the Fuzzy Urban Quality $(F)$. The value of this "constant" $(c)$ is above a certain level $\left(c^{*}\right)$. 
2a. The time $\left(T_{d, k}\right)$ one needs to reach the ordinary daily ${ }^{18}$ points $(d)$ from home (work places, recreational and educational places, green areas, shops ...) should not be higher than a reasonable time $\left(T^{*}\right)$ which is around 15 minutes walking (namely within around 1 $\mathrm{km}$ ). A sky train net (and tube) connects the entire Isobenefit city so that in a few minutes one can comfortably (and aesthetically pleasantly for the view offered) reach also the opposite side of the city.

2b. We call $C$ an urban centrality (in terms of Place, not Space ${ }^{19}$ ) which may be either a particularly pleasant Fuzzy Urban Quality of an area, or a sum of several amenities concentrated in an area, or just one amenity but very attractive. Therefore at least one centrality exists that is reachable from $k$ within $T^{*}$ (in equation $1, d_{c-k}$ is the "time distance" between $C$ and $\mathrm{k}$ ). Each $C$ has a similar overall level of attractiveness, but is not identical in the composition, morphology and location, otherwise we will have a robotic, boring city, without any genius loci throughout its areas, and, in another scale, throughout cities.

2c. Each point would reach natural lands $(N)$ within $T^{*}$.

3. Buildings should be adjacent to each other (compact urban form) in a way to continuously cover areas of at least $1 \mathrm{sq} . \mathrm{km}^{20}$; and these areas connected with nearby built areas (physically and/or by sky train/tubes: in the latter case the overall time, walking + public transport, should be lower than 20 minutes, namely around 5 minutes between proximate centralities by public transport). Idem for the natural land which should continuously cover areas of at least $1 \mathrm{sq} . \mathrm{km}^{21}$ and where all these areas are physically interconnected among them.

\subsection{Isotopia}

We sketch the principles of Isobenefit Urbanism, the urban genotype, whose related phenotypes family can be called Isotopia ${ }^{22}$ :

1. the amenities allocation should tend to ensure a similar accessibility and overall benefit across urban areas;

2. each citizen should be able to reach:

a) the ordinary daily points within 15 minutes walking $\left(T^{*}\right)$;

b) a centrality within $T^{*}$;

c) a natural area within $T^{*}$;

3. buildings should be close to each other, in the same way natural areas (at least 1 continuous sq. $\mathrm{km}$ ) and interconnected.

\footnotetext{
${ }^{18}$ For a visual representation of travel times and activities of a typical 1000 people's simulated average day in America based on 2014 data from the American Time Use Survey (https://www.bls.gov/tus/), see https://flowingdata.com/2015/12/15/a-day-in-the-life-of-americans/

${ }_{19}$ There are two types of centralities: one related to the physical street patterns (geometrically oriented such as Space Syntax); one "adds" attractions to the latter (geographically oriented such as Place Syntax).

${ }^{20}$ With a minimum reasonable width, a part the first point of contact.

${ }^{21}$ See the previous footnote.

22 "Such utopian contributions are not frequent and are necessary to widen scholars' discussion. They had been particularly relevant in history, when consolidated paradigms were revised. We are currently facing quite complex challenges that require, as Buckminster Fuller mentioned in your quote, fighting the existing reality. Therefore, my suggestion is that we should encourage proposals that incorporate utopian strategies to impact scholars' debates. In order to encourage them, we should be more flexible when requiring feasibility or rigorous simulations" (a "Reviewer 5" comment).
} 
Each centrality spontaneously differs from the others, as well as the fuzzy urban quality across areas within the city, and any city elements (architecture, street shapes...).

In addition, small public gardens will be uniformly spread to allow children and seniors to have a green contact by walking within 5 minutes.

Regarding the centralities distribution, if we refer to the archaic monocentric city (a city with just one centrality), the simplistic concept of Isobenefit Urbanism is the following: as one moves away from the centre, another centrality 'compensates' it. More in general: as one moves away from a centrality, another centrality compensates it. Unquestionably the historical centre, its artistic and historical value, its genius loci cannot be replaced by something else, but what we could still try to do, is to offer a sort of compensation (as e.g., la Défense in Paris), without meaning substitutions; thanks to this compensation we will not allow the quality, liveability, palatability decadence of, e.g., the peripheries (if they are the worst area of the city), and of its inhabitants, at least in terms of centralities accessibility.

\section{From Isobenefit urban genotype to urban phenotypes}

To implement this urban genotype a GIS platform linked with other tools enables the proper, and constantly updated, calculation of the five points (1, 2a, 2b, 2c, 3) of the Isobenefit urbanism code involving land use, distances, amenities as briefly illustrated in fig. 4.

We imagine an initial scenario of a natural land with a small group of buildings loosely grouped in a coarse circle of around $2 \mathrm{~km}$ diameter, with a centrality plus daily shops ${ }^{23}$ in its centre; and we see the form formation/evolution (morphogenesis) across time (vertical direction in Fig. 5) according to points 2 and 3 of the Isobenefit urbanism code ${ }^{24}$ : so that each urban point should be within $1 \mathrm{~km}$ from both a natural area and a centrality, and continuously densely covering at least a 1 sq. $\mathrm{km}$ area; natural areas should be physically joined, and urban areas physically or by transport infrastructure joined.

We can easily realize that the urban structure and form evolution can take infinite paths because per each urban morphogenesis step if several alternatives contemporarily satisfy each of the points 2 and 3, an arbitrary component would decide which alternative to select. See the next figure for some urban morphogenesis examples (Fig. 5).

According to environmental local characteristics (orography, water basins, ...) and contingent unpredictable paths in which the city grows, the above areas may be connected among each other, adjacent, generating irregular random forms, or a linear settlement, or an annulus, or be disposed in a series of rings, or in a patchy pattern, or in a punctiform way in which each independent dense settlement morphologically separated and connected with the others by linear public transportation lines (ropeway and tube), or in an infinite range of pattern possibilities.

This growth mechanism also allows a dynamic change and expansion, as it is not pre-designed and static, but, theoretically is infinitely extensible and mutable.

The next fig 6 shows a visual example of the morphology of a megacity as it usually appears, against its counterpart Isobenefit urbanism morphology, holding constant the total available surface and a similar number of inhabitants, therefore assuming a similar economy of agglomeration without incurring to the diseconomy of agglomeration. It is particularly evident the natural land available by following the Isobenefit urbanism morphogenesis, which will drastically reduce objective and quantifiable phenomenon such as urban heat islands (cooling effect of green surfaces and trees), flooding (water absorption from the roots), pollution (tree leaves capturing particulate matter), and increase biodiversity and physically and psychologically healthy daily contact with nature.

\footnotetext{
23 For simplicity we consider the case where each centrality also has daily shops-services-amenities.

${ }^{24}$ For point 1 see (D'Acci 2015).
} 
Among the infinite combinations of land use and shape satisfying the Isobenefit genotype, we can mention the Annulus City and the Punctiform City.

The former is an annulus with $2-3 \mathrm{~km}$ of width, with centralities every $2-3 \mathrm{~km}$ along the annulus, with sky trains and underground transport systems, an internal circular park and external natural and rural land.

The Punctiform City, (Fig. 7) is an interconnected net of small hyperdense urban settlements (Unit Points of $1-3 \mathrm{~km}$ radius, distant $1-8 \mathrm{~km}$ among nearby Unit Points) throughout wild natural and rural land, linked among each other by automatic sky trains and tube.

The Punctiform City rather than a dispersed city is a dispersed concentration: unit points all together generate the Punctiform city which might be equivalent, in terms of inhabitants, to a megacity, better defined as a Megatown, as a net of little hyperdense (in population and compactness) "physical towns" (the unit points), regardless definitions of towns in terms of inhabitants.

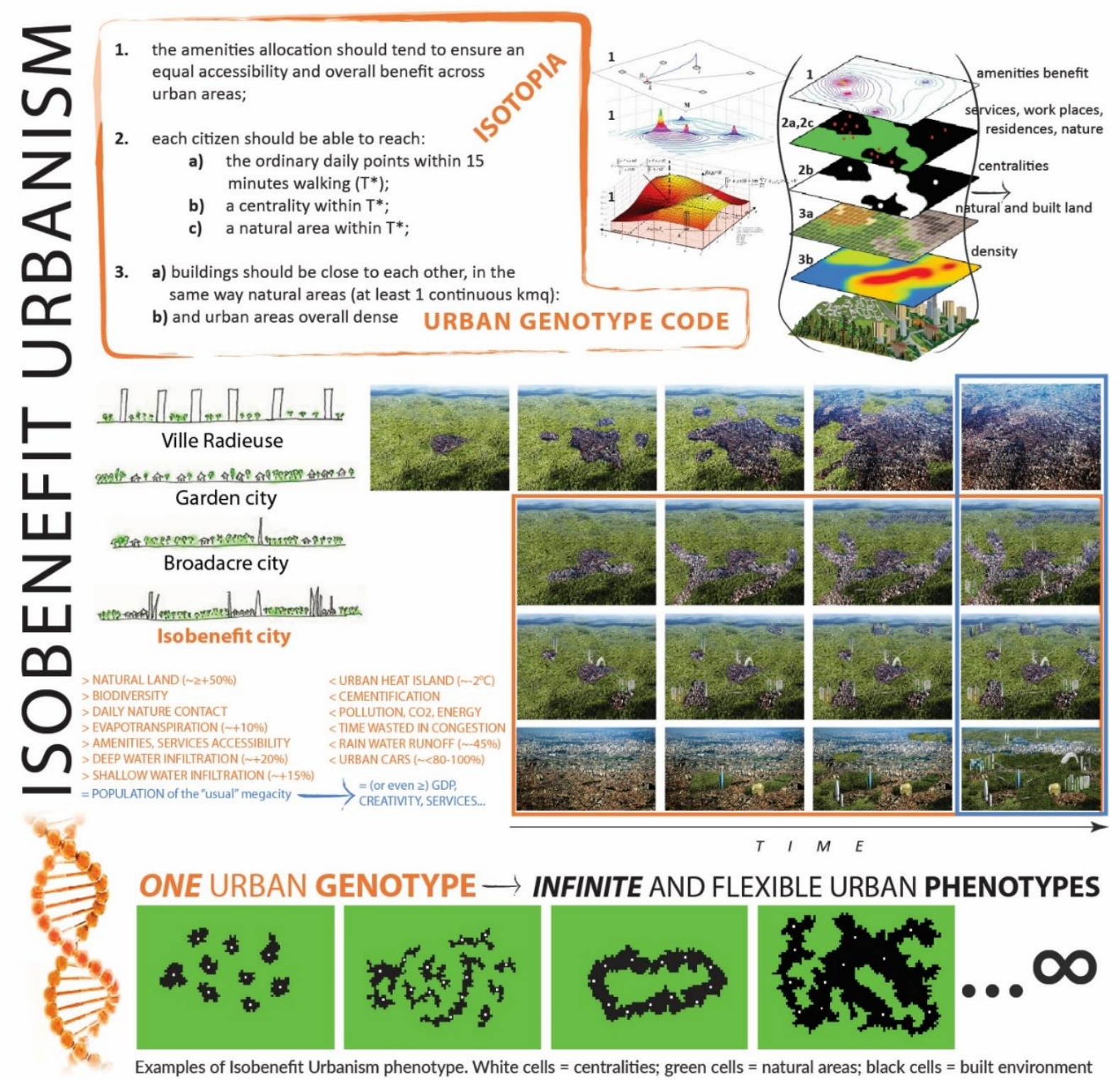

Fig 4. From Isobenefit urban genotype to urban phenotype, and comparison with the typical city growth model 
They may have three different origins from where they could appear in the medium future terms:

I. ex-novo;

II. as the final step of our present cities and megacities by two contemporary phenomena: (1) a deep density improvement (close, large skyscrapers which will become the Unit Points) in some roughly "equidistant" points on the planimetry, and (2) an increase of all the urban parks till they become continuous urban forest. In this scenario the old, historical urban points are maintained;

III. using the old abandoned, or on the path to becoming abandoned, villages/towns, which in several occasions are in ideal equidistant positions among each other, and surrounded by natural and/or agricultural land. In this scenario the old villages/towns will not be touched, as they will represent the genius loci and the identity of each Unit Point which will be built close to them (trying to fit - without touching/ruining - the historical villages in an intriguing game with a hypermodern, ecological and aesthetically attractive design-structures), and using them as an "historical centre" where dwellers will enjoy walking.

In the latter point the new hyper-modern buildings, even without touching the existent, could either create a suggestive eye-catching scenery, or ruin a romantic landscape, unless we find smart ways to hide them, e.g. using natural hills and valleys and underground and/or naturally covered buildings.

Under this circumstance, Punctiform Cities are proposed only as an alternative to demolish old villages: rather than eliminating them and replacing with "modern" structures, Punctiform Cities offer a way to use the old villages as a point of force, a potent nucleus instead of something useless to remove. These old villages may become the city centers and the human dimension of their Unit Points.

\section{Example of Isobenefit Urbanism reasoning for a real estate development case}

Isobenefit Urbanism can be used at different scales, from villages to megacities. For simplicity we see a real estate development plan for a small town in Hampshire (UK), where the announced development of over 10.5 thousand new homes by 2036, in the New Forest District, which assuming two people per home means around $+12 \%$ of the current district population, offers at the same time a spatial-environmental challenge and opportunity.

Within this national requirement, the town of Milford-on-Sea (around 4.450 inhabitants) is presently under pressure to add at least 140 new homes (about $+6 \%$ if we estimate two people per home). Two current proposals, still under discussion, want to build these new homes on the green belt just adjacent to the border of the town, in order to physically continuously expand the existent built area (yellow dashed lines in the satellite view on the top of Fig 8).

Without presenting here the details and Isobenefit Urbanism plan proposals, as out of the scope of this paper and space, we quickly show (Fig. 8) an example of reasoning regarding the spatial location from an Isobenefit Urbanism angle.

The top part (1) of the figure concerns the first point of the Isobenefit Urbanism code; on the satellite view map the red circles are amenities (town historical centre, pleasant natural paths, ...) whose roughly comparative estimated level of attraction for the average person ${ }^{25}$ is indicated with a number (from 1 to 3 ) close to the circle. The "benefit orography" from amenities plotted on the right shows how those amenities and their attractions' flow are spatially distributed (for more details see D'Acci 2015) in the current situation and in the scenario without the adjacent natural ${ }^{26}$ land (or of reduced size, namely reduced appeal): by reducing the size-appeal of the green belt the

\footnotetext{
25 Proportional to the usual number of people actually going there.

${ }^{26}$ For simplicity we call natural also the agricultural land.
} 
medium benefit values through the town coming from amenities becomes half (from 1.9 to 1), and the benefit becomes more unequally spread through the town (coefficient of variation from 0.3 to 0.5 ). The part in the middle left (points $2 \mathrm{a}$ and $2 \mathrm{c}$ of the Isobenefit Urbanism) shows the isochrones for walking time within 10 minutes ${ }^{27}$ from the town centre and daily shops. Below it (point 3) the figure shows how the largest continuous natural land size adjacent to the town is already below $1 \mathrm{~km}^{2}\left(0.6 \mathrm{~km}^{2}\right)$. The other part of the figure shows the isochrones for 10 minutes walking from the current pedestrian access to the natural land at present and in a scenario of built growth on the most adjacent green belt.

URBAN MORPHOGENESIS EXAMPLES: urban scale
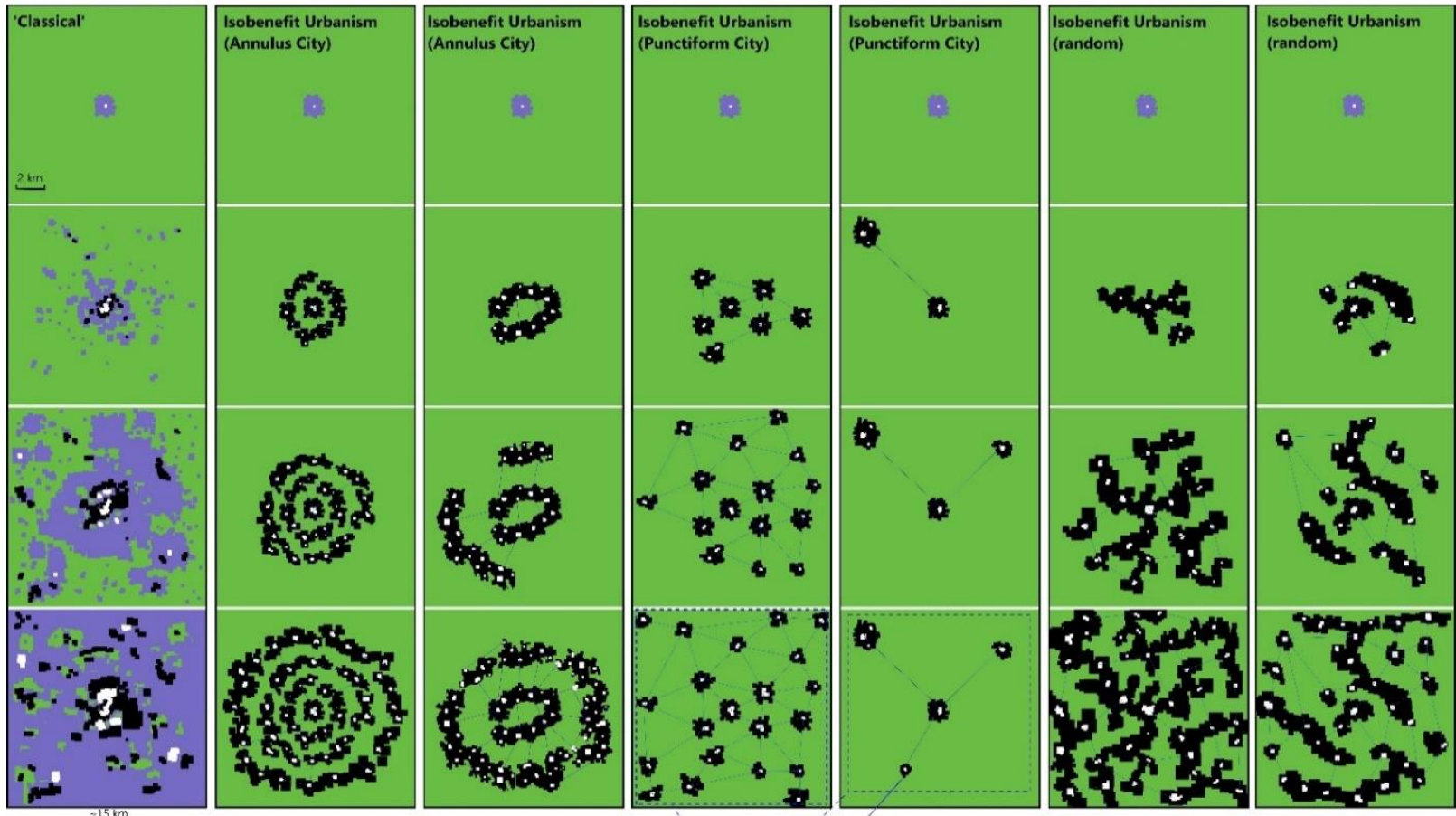

URBAN FORM EXAMPLES: territorial scale
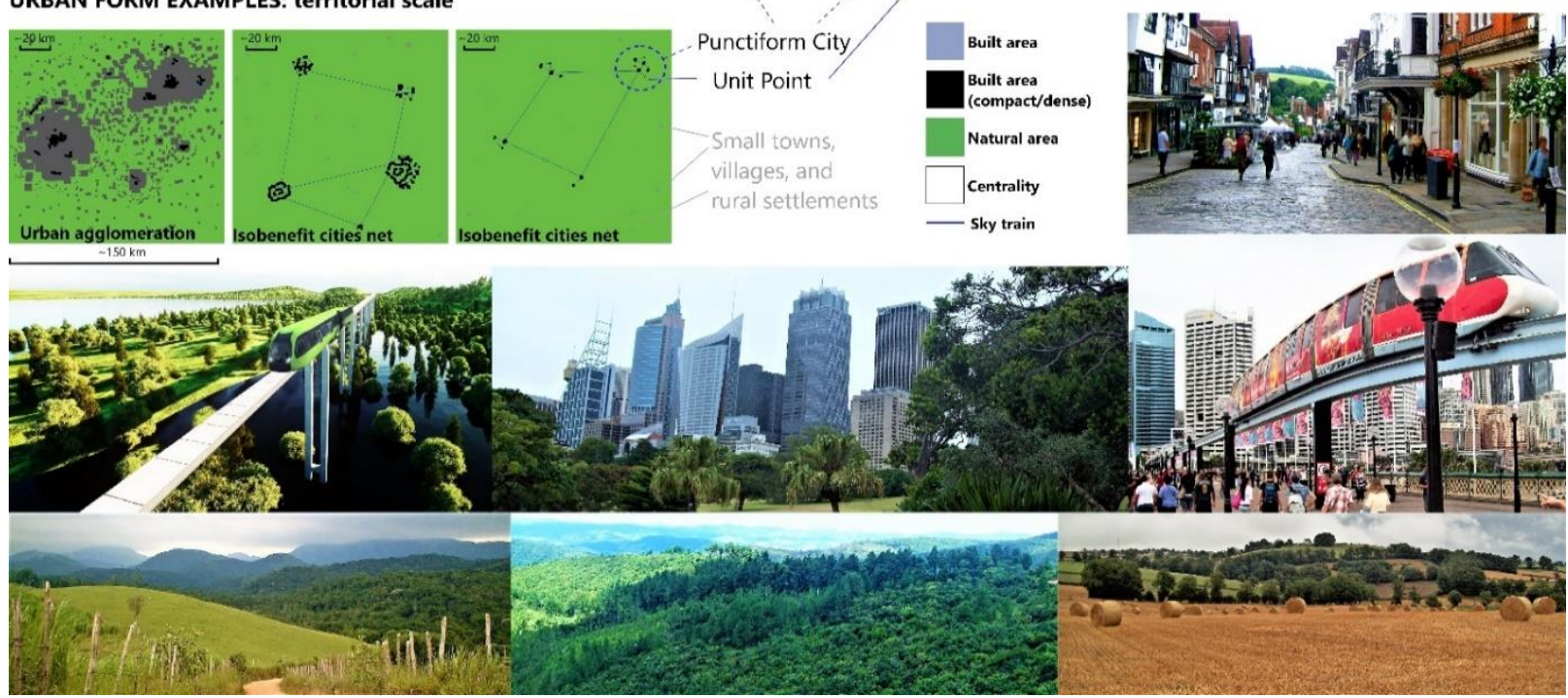

Fig 5. Urban morphogenesis examples. Time on the vertical lines. Picture sources: author's photos (England, Australia, Brazil, France). Green sky train left picture: author's modifications from www.shutterstock.com/video/clip24455867-futuristic-modern-train-passing-on-mono-rail and https://cdn.newsapi.com.au/image/v1/e9465a86c4c46d848d666cf4444769c0

${ }^{27}$ In a village-small town as this, and with a characteristically rural peculiarity, residents might expect even more an easy, fast daily relationship with the surrounding rural area, and local shops. 

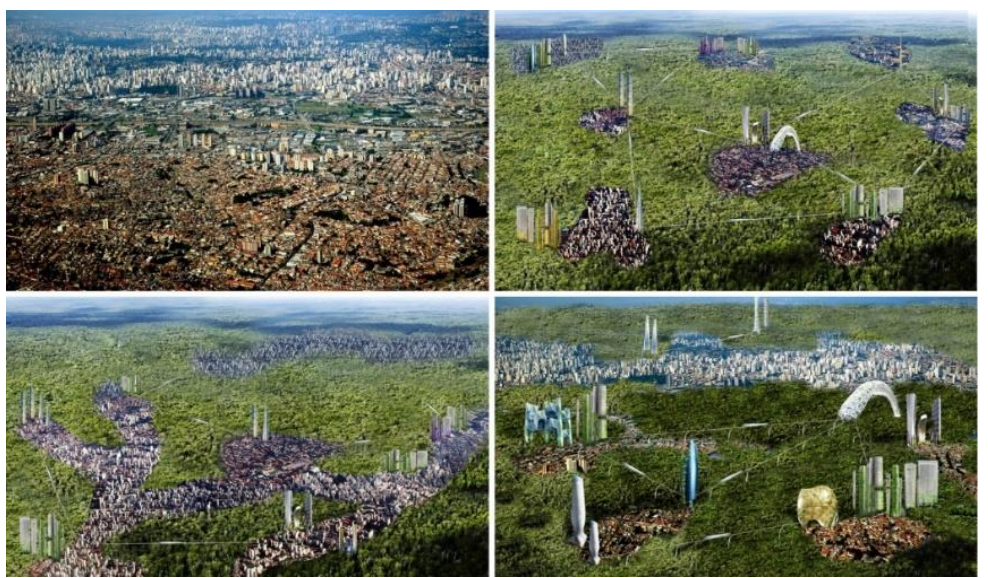

Fig 6. Top left: usual megacity morphology; Top right and bottom: isobenefit megacity morphology counterpart holding similar numbers of inhabitants and the same total available surface.



Fig 7. A Punctiform City (Megatown) of three (top) and four (bottom) Unit Points. Top: author's sketch; bottom: Photoshop simulation from altered images from the web 


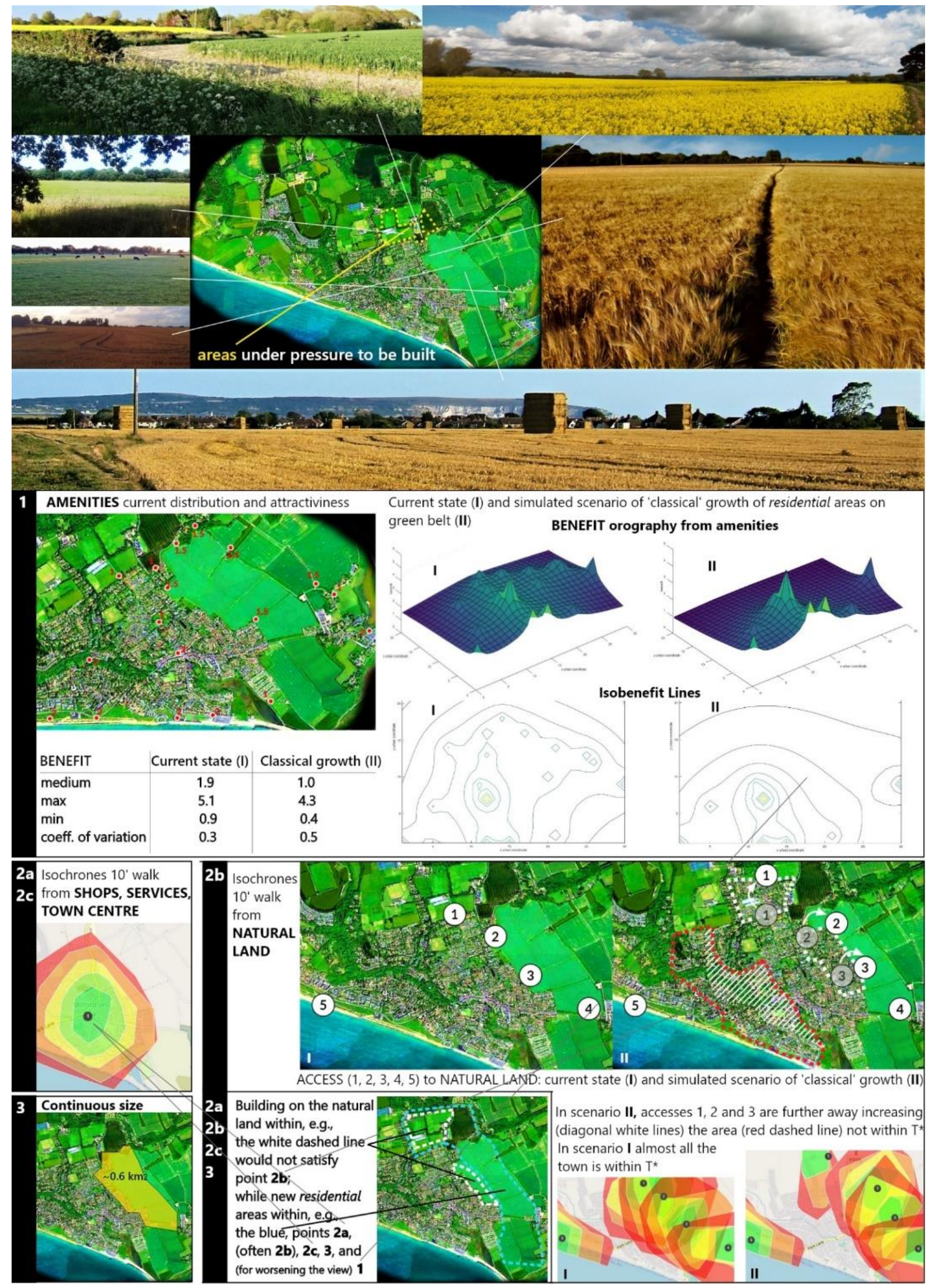

Fig 8. Top: Milford-on-Sea, views of the Green Belt. Author's photos. Bottom: Isobenefit Urbanism reasoning on Milford-on-Sea 
A potential real estate development alternative rough plan idea draft satisfying the Isobenefit Urbanism reasoning can be seen in https://sites.google.com/view/milford-on-sea.

\section{Nature and Urbanity in Isobenefit Urbanism}

The Isobenefit Cities aim is far from being the anti-city criticized by Mumford and many others, referring to the progressive dissolution of the spread American cities, 'sucking the essence out' (Kotkin 2005, p. 118) of the original meaning of city; on the contrary, they will be highly dense and well delimitated cities.

If we agree that cities should be cities, and nature nature, middle ways denature both city and nature. Middle ways offered by dispersed low density cities started in the 1900s with the plan of Los Angeles, nullify the charm and the public life which are among the most vital social ingredients making cities cities. At the same time, they consume natural environment, and get increasingly difficult for citizens to enjoy contact with 'real' nature, which is neither the perfectly kept garden in front of her single-family-house of the spread cities, nor little scattered handkerchiefs of land among endless suburban infrastructures.

We don't intend green areas as merely amenities for the city; the nature intended here are "urban" forest, wild vegetation and agricultural land, as well as the city we intend refers to the sense of urbanity connected to density, compactness, human contact, variety, typical of the pre-industrial towns and contemporary city centres (Fig 9 middle). We write "urban" forest with urban under quotation marks to remind that one of the main point of Isobenefit Urbanism is to keep separated "nature" and "city" in order to maintain their essence, but very close to each other and continuously accessible (within 15 minutes' walk from any urban point): rather than fuzzily merging 28 "nature" and "city" (e.g. Fig. 9, bottom), we discretely merge ${ }^{29}$ them and keep sharply adjacent (e.g. Fig. 9, top and middle).

Fig 4, middle left, shows a synthesized comparison - emphasising the main concepts related to the ambition to merge nature and city - among Isobenefit Cities (particularly the Punctiform City, but it could be any other typology of Isobenefit Urbanism) and some ideas which influenced realizations of cities throughout the world: Ville Radieuse of Le Corbusier (1930), Broadacre city of Wright (1932) and the Garden City of Howard (1898).

Each of them wished to preserve the natural landscape and they do it by proposing different and conflicting solutions.

In a dramatically superficial synthesis the Ville Radieuse is a centralized city whose high-rise multifunctional buildings spread in urban parks occupy $12-15 \%$ of the city. The Broadacre city is a decentralized society in a rural ultra-dispersed "city". They were low-density buildings, individual family houses and occasional high-rise buildings, highly dispersed throughout farms and natural landscapes. The Garden City is a self-contained town with its own centre, parks and work places, surrounded by rural areas, in which a small community lives in individual cottages. Each garden city is connected with the neighbouring garden cities which all spatially gravitate around a main city.

While the Broadacre city is clearly the antithesis of urbanity, it preserves nature and its contact with the "citizens" in their daily life. The Garden City and Ville Radieuse offer a kind of soft nature but with a lack of urbanity. However, the latter, due to speculation and contingency, lost the original meaning of their authors, respectively Howard and Le Corbusier, becoming garden suburbs and anonymous dormitory buildings without the multiuse land/buildings and, therefore, without the vibrant urbanity designed by the original authors.

\footnotetext{
${ }^{28}$ Small and highly anthropized green areas here and there within the city, or example in the bottom of Fig. 9 .

${ }^{29}$ As examples in Fig 9 top and middle: distinctive natural areas and distinctive urban areas.
} 
What Isobenefit Urbanism proposes as a way to merge the city and the country, is to not merge them.

It is neither a soft urbanity nor a soft nature; it is a clear sense of urbanity and a clear sense of nature "merged" by keeping the right density and dimension of urban settlements, and the right dimension and density of natural landscapes.

Contrary to the Garden City ${ }^{30}$ and Ville Radieuse, Isobenefit cities are not directly designed; contrary to the Broadacre City, Ville Radieuse and the Garden City, they are dense independent settlements which combine low-rise with high-rise multifunctional buildings in small entirely "urban" areas; these areas are then connected with others in order to reach a high number of inhabitants enabling economies of scale. Mixed with these areas are parks, woods, small lakes and forests.

Isobenefit Urbanism may also offer a morphological solution for bringing nature and cities close to each other, especially in this highly controversial time regarding the Green Belt, as currently in England. Green wedge urbanism (Lemes 2017), one valuable example among many alternatives, provides a geometrical plan in which the green areas are triangularly arranged (with the vertexes of green isosceles triangle areas starting all together from the centre of the city); while Isobenefit Urbanism is more "liberal" in this sense, as doesn't indicate specific geometries to follow, but is opens to infinite spatial allocation shapes of the green areas. It mixes two elements which, even if apparently contradictory, when they appear together are seen as positive to reach a proper urban life: the anonymity of the city and the human urban dimension.

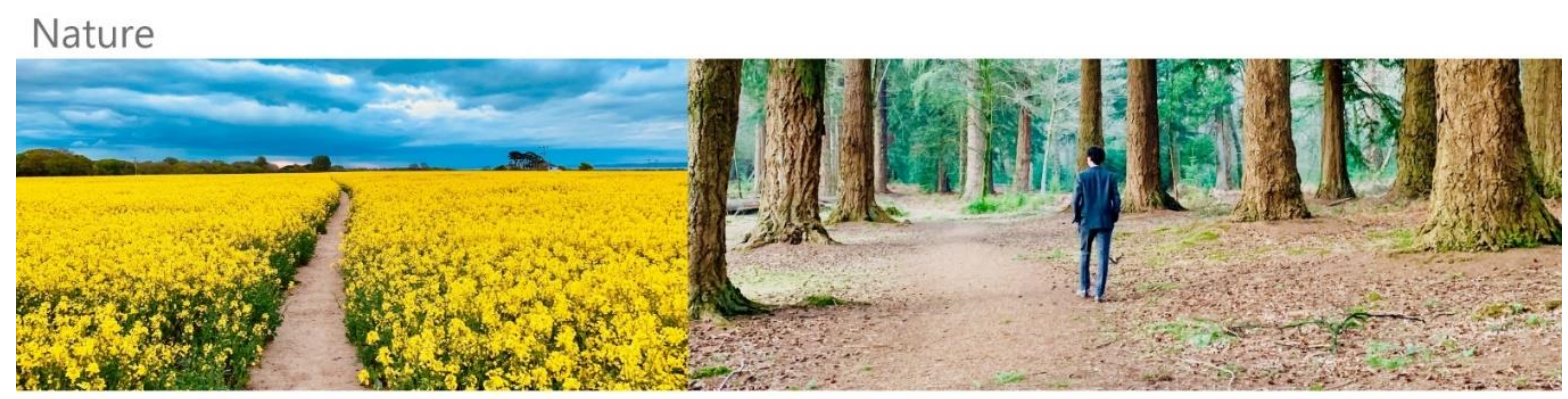

Urbanity

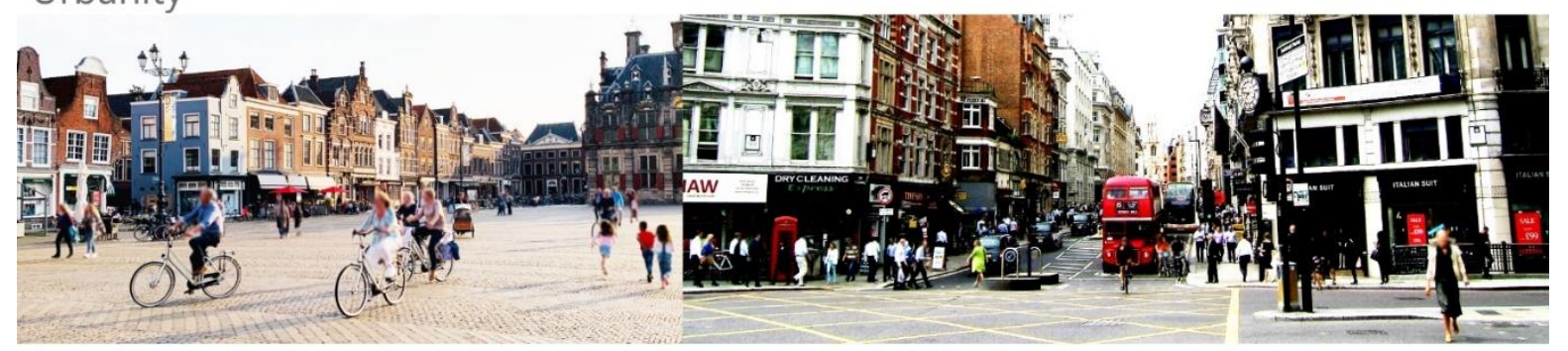

Nature? Urbanity?

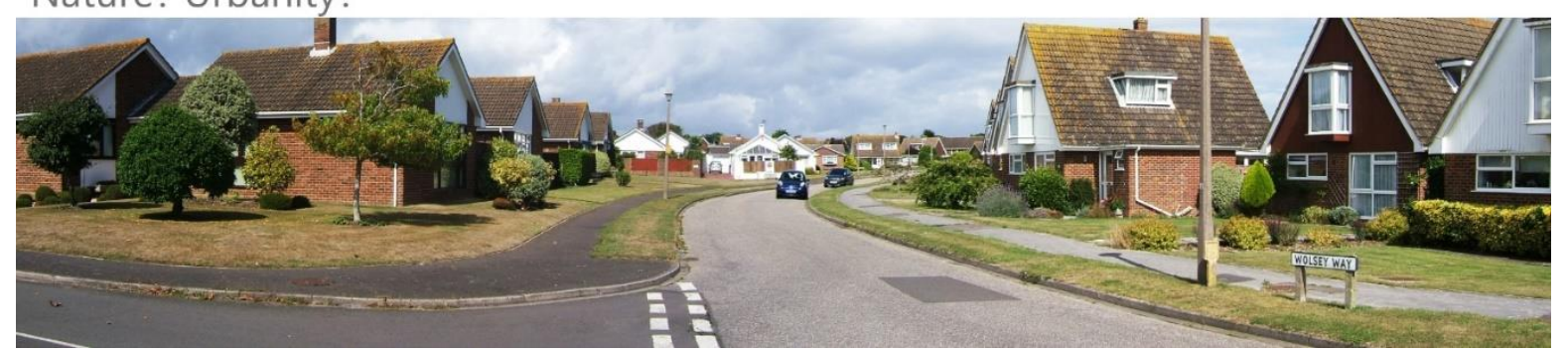

Fig 9. Examples of 'Nature' (top), 'Urbanity' (middle) and of neither of them (bottom, if continuously largely extended). Source: Author's photos

${ }^{30}$ However, each garden city was not directly designed in its strict geometry, but, as Howard himself indicates, the plan should have been adapted to the local situation. 
The anonymity of the urban life, besides alienation and solitude ${ }^{31}$ problems, from some aspects induces a kind of positive psychological freedom and an increased experience of otherness ${ }^{32}$ too and is guaranteed by the high number of inhabitants allowed from the high-rise buildings, the concentration of the settlements and their interconnections.

The human dimension is induced by the intimacy of low-rise buildings micro-areas (mixed with high-rise buildings), the compactness of settlements and their richness of public spaces, which, together with a fine and varied urban texture, guarantee human encounters and the sense of urbanity.

The general aversion against master planning and zoning, was synthesized by Sennett (1970) who blamed planning for having eliminated diversity and creativity.

Inspired by neorationalism (beginning in Italy and Spain in the 1960s), neoclassicism, the British townscape movement and the American ideas of Alexander and Venturi, French planners in the 1970s proposed an architecture urbaine which refused megastructures and re-proposed the old preindustrial city typology (D’Acci 2019).

According to the above postmodernism urban trends, Isobenefit Urbanism aspires to induce the modernist program for a more egalitarian environment but without applying the universality of the modern movement; on the contrary by adopting a post-modern approach which embraces variety according to contexts, and an intimate sense of urbanity.

The latter aspiration of Isobenefit Urbanism is also related to the wish - and, in a post carbon context, the need - to have carless cities for our future, by generating cities as interconnected independent units in which all the main daily activities may be done by walking or biking. In this respect we recall several urban proposals such as the Traditional Neighbourhood Development (TND); the Pedestrian Pocket (PP); the Krier project for within walking distance cities (Krier 1986); the Nishiyama's urban vision of self-governing neighbourhoods "life spheres" related to the machi (a traditional neighbourhood settlement where housing and work were integrated as in traditional villages) (Hein 2008); the sovietic, and some post-sovietic Microdistrict, or Microraion; the compact urban cells of the Cellular City of the MIT Media Lab.

\section{Design Objective Function of Isobenefit Urbanism}

"The main challenge in [...] modifying existing cities or creating new ones is to find the rational principle that will justify the shape modification or guide the design. [...] Planners who choose to dismiss the market forces [...] must replace them with a credible objective function [which] must be expressed clearly, and the outcome has to be measurable" (Bertaud 2018, p. 307, 309).

The urban genotype proposed from Isobenefit Urbanism is aiming to mitigate clear, objective, and quantifiable negative externalities typically associated with urban size such as the urban heat island effect, flooding for over cementification, congestion, car dependence, pollution and emissions from road traffic, distance from natural land, dormitory areas, mono-functional dead urban areas, peripheral areas with poor accessibility to services and amenities, daily commuting times.

It does not intend to achieve the above negative externalities reduction by constraining density, limiting maximum height of buildings, impeding city population size increasing or imposing certain architectural styles. All the above is kept free to feel and follow market forces ${ }^{33}$, personal creativities

\footnotetext{
31 We summarise it in a famous old quote of George Simmel: "Under certain circumstances, one nowhere feels as lonely and lost as in the metropolitan crowd" (Simmel 1903).

${ }^{32}$ Reinterpreting a Baudelaire thought of the mid-nineteenth century " [...] the city can turn people outward, providing them with experiences of otherness. The power of the city to reorient people in this way lies in its diversity. In the presence of difference, people at least have the possibility to step outside themselves, even if it is just for a short while" (Knox 1995, p. 158).

33 See among many Archer and Ling (2012), Manganelli (2015) for an overview of evaluation in real estate investments, and Torre et al. (2017) for a case of soil-take versus buildability valuation.
} 
and decisions, individual assessments, and, more generally, randomness. Under Isobenefit Urbanism, cities can expand as much as they like, as well as the height of buildings and density. It does not impose city size, and precise locations of functions; it leaves these bottom-up processes free, but within a few "rules" helping to alleviate some well-known diseconomies of agglomeration and quantified in the academic literature since decades (footnotes 5, 6, 7, 9, 10). Market forces within Isobenefit Urbanism would still be able to influence local architecture typology and density; there will always be some parts within each area and within the city spontaneously emerging having slightly or largely better locations, views and/or connections.

\section{Considerations on the Isobenefit Urbanism}

Isobenefit Cities do not aim to replace the historical village-town model, but to replace the present, often unliveable, city typologies.

"Disastrous experience with top-down management of cities [...] forced government to reconsider the role of planning" (Portugali, Meyer, Stolk, Tan, 2012).

A famous attack on city planning is the one of Jacob (1961) who indicated how the top-down contrasts "to the way cities develop organically from the bottom up, as a product of multitudes of local decisions, adapting environments in countless ways that add variety and diversity, function and meaning to living cities" (Portugali, Meyer, Stolk, Tan, 2012).

Utopian ideas, and especially utopian realizations (both in societies and in the urban fabric), often generated critics and disappointments. Pinder, among many, launched the need to develop "critical and transformative utopianism that are open, dynamic" (Pinder 2002, p. 229), by leaving "behind the authoritarianism and static projections typically associated with the concept of utopia, and to rethink the potential functions of utopian urbanism in an era all too ready to jettison the very idea of utopia as such" (Pinder 2002, p. 231).

Cities are unique results of personal history; this paper does not tempt to plan ex-novo cities under universal, authoritarian rules, regardless of spontaneous emergence and history.

We can summarize two antagonistic currents of thought, the top down approach, and the bottom up, which Wilson synthesized in the following: "[...] utopians, planners and architects believed that the only solution was to scrap the existing unplanned, irrational cities and build new, planned ones. Today, by contrast, planning, planners and architects are blamed for having caused the current state of our cities by their overweening interference" (Wilson 1991, pp. 150-151).

Isobenefit Urbanism mixes soft planning-utopia (top-down control) and spontaneous emergence (bottom-up evolution).

The first is suggested to avoid "mistakes" due to the market, selfish and/or backward looking points of view, while the second to avoid "mistakes" due to too social and forward-looking points of view, impersonal sceneries entirely and universally planned from the top control, regardless of genius loci and spontaneous variety.

Also from a morphologically geometrical point of view, there will be no strict constrictions.

Traditional zoning has been accused "of being far too rigid, forcing uniform types and density of development where variation would be much better" (Archer and Ling 2012, p. 80).

In this respect, we saw how the Isobenefit Urbanism genotype enables such variety.

We might try to achieve a connection between extensive and local planning. In doing this, it is, from some points of view, close to the incremental planning of Lindblom (1959) based on feedback systems, the advocacy planning of Davidoff (1965) and the Geddes (1915) spirit.

The latter suggested a "style of planning that was a mixture of bottom up and top down, a blend of centralised planning with organic development" (Portugali, Meyer, Stolk, Tan, 2012), while the first (Lindblom and Davidoff) were "not to altogether reject the raison d'être of the rational comprehensive approach to planning but rather to connect it" (Portugali, Meyer, Stolk, Tan, 2012). 
The city is "something changing and developing, rather than an eternal form [...] a good settlement if also an open one: accessible, decentralized, diverse, adaptable, and tolerant to experiment. This emphasis on dynamic openness is distinct from the insistence of environmentalist (and most utopians) on recurrence and stability" (Lynch 1960, p.114 and p. 117).

The Isobenefit cities described in this paper are also dynamically open for unlimited growth (the Annulus City can unlimitedly grow by adding unlimited annulus; the Punctiform City by adding unlimited Unit Points) and free local change and adaptation following natural bottom up local evolution.

The five points of the Isobenefit Urbanism can be achieved in "infinite" ways.

We can think of these points as the genotype; while we can think of the way in which, contextually, they are achieved, as the phenotype.

In other words, these cities should respect this general "code" (genotype) but they are free to do it by following infinite different paths and shapes. We are also able to change the genotype itself according to change of needs-preferences.

The Isobenifit Urbanism genotype does not build cities which are identical all over the place. What it keeps 'identical' is the possibility to walkably enjoy centralities, amenities and natural land.

\section{Conclusion}

Inglehart in his latest book (2018, p. 159) recalls that "humans have evolved to seek meaningful patterns", which slightly evokes me the twentieth canto of the Inferno of the classic masterpiece of Dante Alighieri ("La Divina Commedia"): "considerate la vostra semenza: fatti non foste a viver come bruti, ma per seguir virtute e canoscenza" 34 .

A relevant part in pursuing the above target, is played at the urban-environmental management dimension. In this respect, the ultimate aim of urban design and environmental management development should be, to use the words about development of the Nobel prize winner Sen (1987), in "advancing the richness of human life" (Shaikh 2004). On the contrary, often we see that "cities are increasingly shaped more by the logic of the market than the needs of their inhabitants" (Bayat \& Biekart 2009). It is often firmly argued that we must not - and actually that if we even want to we cannot anyway - stop, or try to constrain/guide the "natural" forces guiding from the bottom-up social processes such as built environments. However, "putting blind faith in markets [...] has taken us to the brink of ecological [...] collapse" (Raworth 2018, p. 70).

The common inaccuracy is to universally project "human behaviour and human self-perception under capitalism - atomistic individualism, egoistic utilitarianism, dependence on markets, the financing of industrialization out of profits, and calculating rationalism -" generalizing them as valid in any context and time rather than the "particular results of the capitalistic mode of production", so that the forces of markets are "seen as natural, immutable laws, similar in every way to the laws of nature", "accepting capitalism as natural and eternal" (Hunt and Lautzenheiser, 2015, pp. 124-129). Or perhaps, if this human behaviour is indeed universal and then fully expressed through capitalism, we need to control it when its outputs turns directly or indirectly against ourselves. Capitalism and liberal views have lot of notable great outputs, but not always (footnote 4) when over applied on the built environment and management of nature. The temporal inertia necessary for the bottom-up self-organization for adjustments related to potential errors at a scale of cities, megacities, forests and the global environment is too long. Once a city is built, it is for centuries. Once a forest and her ecosystem is eliminated, it is for centuries. And the speed at which nowadays we build cities and destroy natural land and ecosystems is tremendously fast. To manage these urban and environmental degenerative dynamics, we saw some among many possible ideas to tempt achieving certain urban environments, by a soft macro top-down

${ }^{34}$ Consider your origin: you were not made to live as brutes, but to pursue virtue and knowledge. 
governance, being designed at the micro level by bottom-up evolutions which is on the basis of city growths. It is a micro spontaneity under macro rules.

Although The ideal city for everyone, for everywhere and for everyday doesn't exist, unideal cities exist and are in front of everyone, everywhere, everyday: crime, traffic, pollution, stress, congestion, greyness, alienation, lack of public spaces and green, urban heat island, urban sprawl, unwalkable cities, urban gettos, cementification, urbanicity and mental issues ...

These pages aspired to, at least, avoid unideal cities, without attempting either to impose entirely planned cities, or to design The ideal city, which doesn't exist, outside, and probably also inside, our minds.

The same is valid for the environment at a more global scale: deforestation, biodiversity loss, CO2 emissions, climate change, natural habitats fragmentation, ecological degradation.

The Isobenefit Urbanism approach exposed offers an alternative proposal to the spatial management of our planet's environment and its biological treasure, played by the urbanization design governance.

\section{References}

Aguiléra A., Voisin M. (2014). Urban form, commuting patterns and CO2 emissions: What differences between the municipality's residents and its jobs? Transportation Research Part A, 69: 243-251.

Archer, W., Ling D.C. (2012). Real Estate Principles: A V alue Approach. McGraw-Hill. New York.

Banister D. (2007a). Urban sprawl and mobility: a UK perspective. Scienze Regionali, 6(3): 99-105.

Banister D. (2007b). Cities, mobility and climate change. Journal of Industrial Ecology, 11(2): 9-11.

Banister, D. (2012) Assessing the reality - transport and land use planning to achieve sustainability. Journal of Transport and Land Use, 5(3): 1-14.

Batty, M. (2014). A theory of city size. Science 340 1418-1419.

Batty, M. (2018). Inventing Future Cities. The MIT Press, Cambridge Massachusetts, London England.

Bayat, A., Biekart K. (2009). Cities of Extremes. Development and Change. 40(5): 815-825.

Bertaud, Alain (2018). Order without Design. How Markets Shape Cities. The MIT press, Cambridge Massachusetts, London England.

Bettencourt L. (2013). The orings of scaling in cities. Science 340: 1438-1441.

Bianchini, F. (1990). The crisis of urban social life in Britain: origins of the problems and possible responses. Planning Practice and Research, 5(3): 4.

Blackmar, F.W. (1926). History of Human Society. Charles Scribner's sons, USA.

Borrego C., Martins H., Tchepel O., Salmim L., Monteiro A., Miranda A. (2006). How urban structure can affect city sustainability from an air quality perspective. Environmental Modelling \& Software, 21: 461-467.

Bowler, D.E., Buyung-Ali, L., Knight, T.M., Pullin (2010). Urban greening to cool towns and cities: A systematic review of the empirical evidence. Landscape and Urban Planning, 97(3): 147-155.

Boyd, R. \& Richerson, P. J. (2009). Culture and the evolution of human cooperation. Philosophical Transactions of the Royal Society of London. Series B, Biological Sciences, 364(1533): 3281-8.

Brakman, S., Garretsen, H., van Marrewijk, C. (2011). The New Introduction to Geographaical Economics. Cambridge University Press. Cambridge, England.

Brandon P.S., Lombardi P., Shen G.Q. (Eds.) (2017). Future challenges for sustainable development within the built environment. Wiley. Oxford.

Bregman, R. (2016). Utopia for realist. Bloomsbury. London.

Brian J. L. Berry \&Adam Okulicz-Kozaryn (2011). An Urban-Rural Happiness Gradient. Urban Geography, 31(6): 871-883. 
Brownstone D., Golob T. (2009). The impact of residential density on vehicle usage and energy consumption. Journal of Urban Economics 65: 91-98

Bulkeley, H., V. Castan-Broto, M. Hodson and S. Marvin (2011). Cities and low carbon transitions. Routledge, London.

Camagni, R. P., \& Salone, C. (1993). Network Urban Structures in Northern Italy: Elements for a Theoretical Framework. Urban Studies, 30(6), 1053-1064.

Carvalho, M. d. G., Bonifacio, M., Dechamps, P. (2011). Building a low carbon society. Energy 36: 18421847.

Chatterton, P. (2013). Towards an Agenda for Post-carbon Cities: Lessons from Lilac, the UK's First Ecological, Affordable Cohousing Community. International Journal of Urban and Regional Research, 37(5): 1654-74.

Chen Y., Li X., Zheng Y., Guan Y. Liu X. (2011). Estimating the relationship between urban forms and energy consumption: A case study in the Pearl River Delta, 2005-2008. Landscape and Urban Planning 102: 33-42.

Cheney, D.L. (2011). Extent and limits of cooperation in animals. PNAS, June 28, vol. 108 suppl. 2.

Cloutier, S., Larson, L., Jambeck, J. (2013). Are sustainable cities "happy" cities? Associations between sustainable development and human well-being in urban areas of the United States. Environment, Development and Sustainability. November 2013.

Conaway R., Laasch O. (2014). Principles of Responsible Management Global Sustainability, Responsibility, and Ethics. Cengage Learning.

Davidoff, P. (1965). Advocacy and pluralism in planning. In: Faludi, A. (ed.) A Reader in Planning Theory, pp. 277-296. Pergamon, Oxford, UK.

D'Acci L. (2019). On Urban Morphology and Mathematics. In: D'Acci L. (Ed) (2019), The Mathematics of Urban Morphology. Birkhäuser, (Springer Nature), Cham.

D’Acci L. (2015). Mathematize urbes by humanizing them: cities as isobenefit landscapes. Psychoeconomical distances and personal isobenefit lines. Landscape and Urban Planning, 139: 63-81.

Dodman D. (2009). Blaming cities for climate change? An analysis of urban greenhouse gas emissions inventories. Environment \& Urbanization, 185 Vol 21(1): 185-201.

Easterlin, R.A., Angelescu, L., \& Zweig, J.S. (2011). The Impact of Modern Economic Growth on Urban Rural Differences in Subjective Well-Being. World Development, 39(12): 2187-2198.

Echenique M., Hargreaves A., Mitchell G., Namdeo A. (2015). Growing cities sustainably. JAPA, 78(2): 121-137.

Evans, R. (1997). Regenerating town centres. Manchester University Press, Manchester.

Faluenbach, B. (1995). Utopia at the end of the twentieth century: current discussion in Germany, in Fiedler, B. (ed.), Social Utopias of the Twenties: Baubaus, Kibbuts and the dream of the new Man. Germany, Muller and Busmann Press, Berlin.

Fehr, E. \& Gächter, S. (2002). Altruistic Punishment in Humans. Nature, 415(6868): 137-40.

Fehr, E. \& Schmidt, K. (1999). A Theory of Fairness, Competition, and Cooperation. The Quarterly Journal of Economics, 114(3), 817-68.

Fragkis M., Lobo J., Strumsky D., Seto K. (2013). Does size matter? Scalin of CO2 emissions and U.S. urban areas. PLOS ONE, 8(6): e64727.

Fujita, M., Krugman, P., Venables, A.J. (2001). The Spatial Economy. MIT press. Cambridge Massachusetts, London England.

Gabor, D. (1963). Inventing the Future. [Edition 1964, Pelikan Books].

Gächter, S., Renner, E., \& Sefton, M. (2008). The long-run benefits of punishment. Science, 322(5907: 1510.

Gaspar, J. \& Glaeser, E. (1998). Information Technology and the Future of Cities. Journal of Urban Economics 43(1): 136-156.

Geddes, P. (1915/1949). Cities in Evolution: An Introduction to the Town Planning Movement and to the Study of Civics. Williams \& Norgate, London.

Giuliano G., Small K., (1993). Is the journey to work explained by urban structure? Urban Studies, 30: 1485-1500.

Glaeser E., Kahn M., (2010). The greenness of cities: carbon dioxide emissions and urban development. Journal of Urban Economics 67: 404-418.

Glaeser, E.L. (2008). Cities, Agglomeration, and Spatial Equilibrium. Oxford University Press. New York. 
Gombrich, E.H. (1936). A little history of the world. YALE, Originally published unde the title Weltgeschichte von der Urzeit bis zur Gegenwart by Steyrermuhl - Verlag, Vienna.

Gomi, K, Shimada, K., Matsuoka, Y., Naito, M. (2007). Scenario study for a regional low-carbon society. Sustainable Science 2:121-131.

Gordon P., Wong, H., (1985). The cost of urban sprawl: Some new evidence. Environment and Planning A, 17: 661-666.

Grazi F., van den Bergh J., van Ommeren J., (2008). An Empirical Analysis of Urban Form, Transport, and Global Warming. The Energy Journal, 29(4): 97-122.

Hall P., and Pain K. (2006). The Polycentric Metropolis. Sterling, London.

Hein C. (2008). Machi: Neighborhood and Small Town. The Foundation for Urban Transformation in Japan. Journal of Urban History 35: 75-107.

Heinonen J., Jalas M., Juntunen J., Ala-Mantila S., Junnila S. (2013). Situated lifestyles: II. The impacts of urban density, housing type and motorization on the greenhouse gas emissions of the middleincome consumers in Finland. ENVIRONMENTAL RESEARCH LETTERS 8, 035050.

Hens L. (2010). The challenge of the sustainable city. Environment, Development and Sustainability, 12, pp. 875-876.

Hickman R., Banister D. (2014). Transport, Climate Change and the City. Routledge, Abingdon. pp. 400.

Holden E., Norland I., (2005). Three Challenges for the Compact City as a Sustainable Urban Form: Household Consumption of Energy and Transport in Eight Residential Areas in the Greater Oslo Region. Urban Studies, 42(12): 2145-2166.

Howard E. (1898) [2010]. To-morrow: A Peaceful Path to Real Reform. Cambridge University Press. New York.

Hunt E.K., Lautzenheiser M., (2015). History of Economic Thought. A critical perspective. Routledge, New York.

Inglehart R.F. (2018). Cultural Evolution. University Cambridge Press, Cambridge, UK.

Jackson Laura E. (2003). The relationship of urban design to human health and condition. Landscape and Urban Planning, 64(4): 191-200.

Jacob J. (1961). The Death and Life of Great American Cities. Random House, New York.

Johnson A.W., Earle T.K. (2000). The Evolution of Human Societies: From Foraging Group to Agrarian State. Stanford University Press, Stanford.

Kasanko, M., Barredo, J.I., Lavalle, C., McCormick, N., Demicheli, L., Sagris, V., Brezger, A., 2006. Are European Cities Becoming Dispersed? A Comparative Analysis of Fifteen European Urban Areas. Landscape and Urban Planning, 77:111-130.

Keirstead J., Shah N. (2011). Calculating minimum energy urban layouts with mathematical programming and Monte Carlo analysis techniques. Computers, Environment and Urban Systems, 35: 368-377

Kennedy C., Pincetl S., Bunje P. (2011). The study of urban metabolism and its applications to urban planning and design. Environmental Pollution, 159: 1965-1973.

Knoke, K. (1996). Bold New World: The Essential Road Map to the Twenty-First Century. Kodansha, New York.

Knox P. (1995). Urban Social Geography. Longman, 3rd edition, Singapore.

Kotkin, J. (2005). The City, A Global History. Phoenix. London.

Krier L. (1986). The Competition of Washington DC. Washingotn, Paris, Toulouse, Nimes. Archives de l'Architecture Moderne. Brussels.

Larson K. (2012). Brilliant design to fit more people in every city. TEDx Boston: June 2012. http://cities.media.mit.edu/projects/examples

Lee S., Lee B. (2014). The influence of urban form on GHG emissions in the U.S. house hold sector. Energy Policy 68: 534-549.

Lefebvre H. (1976 [1973]). The survival of capitalism. Translated by F. Bryant, Allison and Busby, London.

Lefebvre H. (2009 [1970]). Reflections on the politics of space. In N. Brenner and S. Elden (eds.), State, space, world: selected essays, translated by N. Brenner and S. Elden, University of Minnesota Press, Minneapolis, MN.

Lehmann, S. (2014). Low Carbon Cities. Routledge. New York.

Lemes F. (2017). Green Wedges Urbanism. Bloomsbury. London and New York.

Li X., Gar-On Yeh A., (2000). Modelling sustainable urban development by the integration of constrained cellular automata and GIS. International Journal of Geographical Information Science, 14(2) 131-152.

Lindblom C.E. (1959). The science of muddling through. Public Admin. Rev. 19: 78-88. 
Liu C., Shen Q., (2011). An empirical analysis of the influence of urban form on household travel and energy consumption. Computers, Environment and Urban Systems 35: 347-357.

Liu Y., Song Y., Arp H. (2012). Examination of the relationship between urban form and urban ecoefficiency in china. Habitat International 36: 171-177.

Louf R., Barthelemy M. (2014a). Scaling: lost in the smog. Environment and Planning B, 41:767 - 769.

Louf R., Barthelemy M. (2014b). How congestion shapes cities: from mobility patterns to scaling. Scientific reports, 4:5561.

Lovelock, J. (2014). A rough ride to the future. Penguin. London.

Lowry J., Lowry M. (2014). Comparing spatial metrics that quantify urban form. Computers, Environment and Urban Systems, 44: 59-67.

Lyle, J.T. (1994). Regenerative Design for Sustainable Development. Wiley, New York.

Lynch, K. (1960). The Image of the City. MIT Press, Cambridge, Massachusetts.

Ma K-R., Banister D. (2007), Urban spatial change and excess commuting. Environment and Planning A, 39: 630-646

Makido Y., Dhakal S., Yamagata Y. (2012). Relationship between urban form and CO2 emissions: Evidence from fifty Japanese cities. Urban Climate, 2: 55-67.

Manganelli B. (2015). Real estate investing. Springer, Cham.

Martins H. (2012). Urban compaction or dispersion? An air quality modelling study. Atmospheric Environment, 54:60-72.

Matsuoka, Rodney H. \& Kaplan, Rachel (2008). People needs in the urban landscape: Analysis of Landscape And Urban Planning contributions. Landscape and Urban Planning, 84(1): 7-19.

McCann P. van Oort F. (2009). Theories of Agglomeration and Regional Economic Growth: A Historical Review. In: Capello R., Nijkamp P. (Eds.), Handbook of Regional Growth and Development Theories. Elgar, Cheltenham, Northampton.

McCarty J., Kaza N. (2015). Urban form and air quality in the United States. Landscape and Urban Planning, 139: 168-179.

McIntosh J., Trubka R., Kenworthy J., Newman P. (2014). The role of urban form and transit in city car dependence: Analysis of 26 global cities from 1960 to 2000. Transportation Research Part D 33: 95-110.

Meijers, E.J. (2007). Synergy in Polycentric Urban Regions. Delft University Press.

Merrifield, A. (2013). The Urban Question under Planetary Urbanization. International Journal of Urban and Regional Research, 37(3): 909-22.

Mindali O., Raveh A., Salomon I. (2004). Urban density and energy consumption: a new look at old statistics.Transportation Research Part A, 38: 143-162.

Mitani, J.C. (2009). Cooperation and Competition in Chimpanzees: Current Understanding and Future Challenges. Evolutionary Anthropology 18:215-227.

Mitchell G., Hargreaves A., Namdeo A., Echenique M., (2011). Land use, transport, and carbon futures: the impact of spatial form strategies in three UK urban regions. Environment and Planning $A$, 43: 2143-2163.

Mohajeri N., Gudmundsson A., French J. (2015). CO2 emissions in relation to street-network configuration and city size. Transport Research Part D, 35: 116-129.

Moloney, S. Horne, R E. and Fien J. (2010) Transitioning to Low Carbon Communities - From Behaviour Change to Systemic Change: Lessons from Australia. Energy Policy, 38(12): 76147623.

Naisbitt, R. (1995). The Global Paradox. Avon Books, New York.

Negroponte, N. (1995). Being Digital. Vintage Books, New York.

Okulicz-Kozaryn, Adam (2015). When Place is Too Big: Happy Town and Unhappy Metropolis. 55th Congress of the European Regional Science Association: "World Renaissance: Changing roles for people and places", 25-28 August 2015, Lisbon.

Oliveira E., Andrade J., Makse H. (2014). Large cities are less green. Scientific reports, 4:4235.

Pinder, D. (2002). In defense of utopian urbanism: imagining cities after the 'end of utopia'. Geografiska Annaler, 84 B (3-4): 229-241.

Pinder, D. (2013). "Reconstituting the possible: Lefebvre, utopia and the urban question". International Joumal of Urban and Regional Research, Article first published online: 30 AUG 2013. DOI: 10.1111/1468-2427.12083. 
Portugali, J., Meyer, H., Stolk, E., Tan, E. (Eds.) (2012). Complexity Theories of Cities Have Come of Age. Springer.

Preston C.J. (2018). The Synthetic Age: Outdesigning Evolution, Resurrecting Species, and Reengineering Our World. MIT press, Cambridge USA.

Raworth, K. (2018). Doughnut Economics. Random House Business Books, Penguin, London.

Schubert J., Wolbring T., Gill B. (2013). Settlement Structures and Carbon Emissions in Germany: The Effects of Social and Physical Concentration on Carbon Emissions in Rural and Urban Residential Areas. Environmental Policy and Governance, 23: 13-29.

Schwanen T., 2002. Urban form and commuting behaviour: a cross-European perspective. Tijdschrift voor Economische and Sociale Geografie, 93: 336-343.

Schwanen T., Dieleman F., Dijst M., (2001). Travel behaviour in Dutch monocentric and policentric urban systems. Journal of Transport Geography, 9: 173-186.

Schwanen T., Dieleman F., Dijst M., (2002). Car use in Netherlands Daily Urban Systems: does polycentrism result in lower travel times? Urban Geography, 24:5, 410-430.

Schwanen T., Dijst M., Dieleman F., (2002). A microlevel analysis of residential context and travel time. Environment and Planning A 34(8): 1487-1507.

Schwanen T., Dijst M., Dieleman F., (2004). Policies for Urban Form and their Impact on Travel: The Netherlands Experience. Urban Studies, 41(3): 579-603.

Sen, A. (1987). On ethics and economics. Basil Blackwell. Oxford.

Sennett, R. (1970). The Use of Disorder: Personal Identity and City Life. Random House. New York.

Seyfang, G. (2010). Community action for sustainable housing: Building a low-carbon future. Energy Policy 38, 7624-7633.

Shaikh, N. (2004). Amartya Sen: A More Human Theory of Development. Asia Society.

Simmel, G. (1903). The Metropolis and Mental Life.

Skea, J., Nishioka, S. (2008). Policies and practices for a low-carbon society. Climate Policy 8, S5-S16.

Sørensen, Jens F. L. (2014). Rural-Urban Differences in Life Satisfaction: Evidence from the European Union. Regional Studies, 50(3): 1451-1466.

Swyngedouw, E. (2009). The Antinomies of the Postpolitical City: In Search of a Democratic Politics of Environmental Production. International Journal of Urban and Regional Research, 33(3): 601-20.

Toffler, A. (1979). Future Shock. Pan Books, London.

Toffler, A. (1980). The Third Wave. Bantam Books, New York.

Torre C.M., Morano P., Tajani F. (2017). Saving soil for sustainable land use. Sustainability 9(3): 350.

Toynbee, A. (1972). A Study of History. Oxford University Press and Thames \& Hudson Ltd, London.

United Nations, Population Division of the Department of Economic and Social Affairs (16 June 2018). 2018 Revision of World Urbanization Prospects. https:/ / esa.un.org/unpd/wup/

van Kamp, I., Leidelmeijer, K., Marsman, G., \& de Hollander, A. (2003). Urban environmental quality and human well-being: Towards a conceptual framework and demarcation of concepts; a literature study. Landscape and Urban Planning, 65(1-2): 5-18.

Wang S., Fang C, Wang Y., Huang Y., Maa H. (2015). Quantifying the relationship between urban development intensity and carbon dioxide emissions using a panel data analysis. Ecological Indicators 49: 121-131.

Wang Y., Hayashi Y., Chen J., Li Q. (2014). Urban Form and Transport CO2 Emissions: An Empirical Analysis of Beijing, China. Sustainability, 6: 4558-4579.

Williams K, Burton E and Jenks M (2000) Achieving Sustainable Urban Form, Routledge, London.

Wilson, E. (1986). Biophilia. Harvard University Press. Boston.

Wilson, E. (1991). The Sphinx in the City: Urban Life, the Control of Disorder, and Women. Routledfe, London. Wright, F.L. (1932). The Disappearing City. W. F. Payson. New York.

Zhang, WenJun (2008). A forecast analysis on world population and urbanization process. Environment, Development and Sustainability, 10(6): 717-730. 